\title{
DID ANTITRUST POLICY CAUSE THE GREAT MERGER WAVE?*
}

\author{
GEORGE BITTLINGMAYER \\ Washington University
}

\section{INTRODUCTION}

$\mathrm{P}$ ERHAPS as much as one-half of U.S. manufacturing capacity took part in mergers during the years 1898 to 1902 . These mergers frequently included most of the firms in an industry and often involved firms that had been fixing prices or that had been operated jointly through the legal mechanism of an industrial trust. The histories of Standard Oil and U.S. Steel provide well-known instances in which merger followed looser forms of organization in what has come to be known as the Great Merger Wave. What caused this rapid change of industry structure? The Sherman Antitrust Act was passed in 1890, and the first crucial decisions making price fixing illegal-Trans-Missouri (1897), Joint Traffic (1898), and Addyston (1899) - occurred just before or during the first stages of the merger wave. ${ }^{1}$ Merger of competing firms remained unchallenged until 1904.

Although it certainly seems plausible that antitrust policy caused the Great Merger Wave, the question has never been looked into at length, and some influential studies of the mergers and of early antitrust policy play down the possibility of a connection. This is puzzling because the search for alternatives has not borne fruit. One reason economists may be

\footnotetext{
* A conversation with Lester Telser led me to write this paper, and his comments have proved to be a great aid. I thank Yale Brozen, Meyer Burstein, Alfred Chandler, Nolan Clark, Frank Easterbrook, Michael Knoll, Naomi Lamoreaux, William Landes, John Martin, Frederick Miller, Edward Snyder, Barry Weingast, and an anonymous referee for useful comments and suggestions. My expressions of gratitude should not be taken to imply, however, that those who have helped me necessarily agree with my methods or conclusions. Kevin Sullivan provided expert research assistance. This work was supported in part through the summer grant program of the Graduate School of Business Administration of the University of Michigan.

${ }^{1}$ United States v. Trans-Missouri Freight Ass'n, 166 U.S. 290 (1897); United States v. Joint Traffic Ass'n, 171 U.S. 505 (1898); and United States v. Addyston Pipe \& Steel Co., 175 U.S. 211 (1899). Judge William Howard Taft's Court of Appeals opinion, U.S. v. Addyston, 85 Fed. 271 (6th Cir. 1898), aff'd, was also influential, as I show below.
}

[Journal of Law \& Economics, vol. XXVIII (April 1985)]

(C) 1985 by The University of Chicago. All rights reserved. 0022-2186/85/2801-0006 $\$ 01.50$ 
inclined to dismiss the influence of cartel policy, and why the possibility has never been pressed, comes from the presumption that firms would choose merger over price fixing if they could because merger avoids a host of problems that cartels face. Why should monopoly-minded firms have to be forced to merge at the point of a bayonet? The answer, of course, is that firms will prefer cartels to merger if the gains are greater. If there are diseconomies from merger and if the available monopoly gains are not large, the preferred choice may very well be cartelization, making it at least conceivable that the introduction of a law against price fixing swung the balance in favor of merger.

This argument assumes that the motive for both cartels and mergers is monopoly gain. However, the idea that the motive may not be monopoly at all also seems worth exploring, especially since many firms seemed to prefer the vagaries of a cartel agreement to the more secure coordination of a merged existence. For example, cartels and mergers may be cooperative attempts to solve market problems that do not have a noncooperative solution. One focus of such an explanation, and the one that I will emphasize, is the integer or fixed-cost problem. This is a well-known instance in which there is no competitive equilibrium. As always, the choice between two theories should be governed by their ability to explain the facts, and I hope to show that an explanation based on the desire to remedy the problems posed by fixed costs has at least as much going for it in the case of the Great Merger Wave as an explanation based on simple greed.

I should emphasize that these two explanations, alone or together, do not provide a general theory of merger; there are certainly reasons other than a desire for monopoly gain or a desire to remedy market failure stemming from fixed costs why firms might merge. My primary aim is to see whether a reasonable theoretical foundation can be constructed for the view that changes in antitrust policy caused the large year-to-year variations in merger activity that took place in the late nineteenth and early twentieth centuries and that converted many cartels to single-firm organization. This paper is not an attempt to explain horizontal mergers in general, and I do not rule out the possibility that something like U.S. Steel would have been formed eventually even if the antitrust laws had never been passed.

This study is organized as follows: Section II reviews two explanations for cartels and merger and summarizes their implications for the organization of an industry. Section III covers developments in turn-of-thecentury antitrust policy, and Section IV presents data on the U.S. and U.K. mergers. Section V looks at two prominent industries that participated in the 1898-1902 merger wave-railroading and iron and steel-and reviews evidence from several other industries where there seems to have 
been a link between antitrust and merger. Section VI considers the objections that have been raised against the existence of such a link, and Section VII looks at the possibility of a connection between antitrust and merger for the period 1905-50. It also contains a statistical investigation for the years 1895-1920 of the relation among merger, antitrust policy, and stock prices.

\section{Monopoly, Collusion, and Industry Organization}

The familiar explanation for cartels and anticompetitive mergers begins, at least implicitly, with the analysis of competitive markets and emphasizes the gains from competition. Competition between firms brings prices down to marginal cost, and the entry and exit of firms leads to prices that cover the costs of the marginal firm in the long run. It is useful to recall two of the key assumptions in this analysis: average costs of the firm decrease to a certain point and then increase, and the number of firms is "large." If the firms in an industry can get together and form a cartel or merge, they may be able to restrict output and raise prices at the expense of the consumer.

The analysis of cartels has focused on the costs and benefits of collusion, often as a subtopic in the economics of information. Ultimately, of course, an increase in price will lead to new entry, but short of provoking new entry, the gains accruing to monopoly-minded producers are limited by the difficulty of agreeing on a division of the profits and of detecting cheating and enforcing collusion. ${ }^{2}$ In particular, the fewer the number of sellers in an industry, the easier it is for them to collude. It should be noted, however, that there is a certain tension or inconsistency between the assumption of large numbers of firms in the model of competition used as a benchmark and the result that collusion is more likely when the number of firms is small. Various other factors linked with the difficulty or ease of collusion have also been mentioned, but the number of firms appears on every list. ${ }^{3}$

2 The path-breaking analysis of George J. Stigler, A Theory of Oligopoly, in The Organization of Industry 39 (1968), substituted the calculus of self-interest for boot-strap explanations of collusion.

${ }^{3}$ George J. Stigler, The Theory of Price 219-20 (2d ed. 1966), cites several factors that make forming and policing agreements more difficult: more numerous firms, a more complex product market, and more rapid changes in supply and demand. Frederic M. Scherer, Industrial Market Structure and Economic Performance 199-200 (1980), also places emphasis on the number of competitors. Richard A. Posner \& Frank H. Easterbrook, Antitrust 336-38 (2d ed. 1981), list twelve facilitating factors. (Although their preceding discussion concerns "tacit collusion," their list appears to apply to collusion in general.) Of these twelve, eight are concerned with the problem of detecting cheating and enforcing collusion. These eight are seller concentration, the existence of a competitive fringe, buyer concentra- 
It might seem from this sketch of models of collusion that the firms in an industry bent on getting monopoly gain will prefer merger to price fixing because cartels often break down and because the costs of agreeing on a division of prospective monopoly gains are incurred only once, while cartel enforcement costs are a recurring expense. This is a natural supposition, and attempts to explain the turn-of-the-century mergers in many cartelized industries have focused on developments that made it easier to create and operate large firms-changes in corporation law, improvements in communication and transportation, and the growth of organized exchanges - instead of changes that raised the costs of cartelization. ${ }^{4}$ However, the emphasis on factors that facilitated the formation of large firms may still be wrong if the diseconomies or other costs associated with merger are sufficiently large and if the prospective monopoly gains are small.

For example, suppose that a monopolistically inclined industry faces inelastic demand up to a certain price and infinitely elastic foreign or potential competition above that price. Also assume that there are some, perhaps only slight, diseconomies from merger. ${ }^{5}$ This is a simple model: the profit-maximizing price for both the cartel and the merged firm will be just below the import price even if the merged firm's costs are higher. But consider the implications. If the cartel breaks down 50 percent of the time, the industry will remain a cartel only if the incremental costs of merger (per time period) are more than one-half the current monopoly gain. This implies either substantial diseconomies of scale or fairly effective potential competition. For a given cost penalty from merger, the incremental gain from cartelization over merger increases as the durability of the cartel increases and as the cartel's current margin decreases. For some combination of low-enough monopoly returns and high-enough cost penalties from merger, cartels will be preferred. ${ }^{6}$ In short, there is

tion, standardization of the product, the degree of heterogeneity in vertical integration across firms, whether nonprice competition is important, the variability of demand, and the use of sealed bids.

4 The literature on this subject is discussed in Section VI below.

5 These assumptions constitute a modification of those employed in George J. Stigler, Monopoly and Oligopoly by Merger, in The Organization of Industry 95 (1968), which assumes no diseconomies from merger and a less than instantaneous supply response to prices above the competitive level.

${ }^{6}$ Let $P$ be the price above which the cartel or merged firm faces competition, $C$ the constant unit costs of the cartel, $M$ the constant unit costs of the merged firm, and $x$ the probability that the cartel will function in a given period. The expected gains to merger per unit of output each period are $P-M-\mathrm{x}(P-C)$, assuming that the cartel just covers costs when it breaks down. Clearly, these gains are directly related to the monopoly margin and inversely related to the durability of the cartel and the cartel margin. Specifically, the cartel 
nothing inherently suspicious about a world in which firms prefer cartels to merger as a way of extracting monopoly rents and in which the enforcement of a law against price fixing leads those firms to merge.

So far, I have assumed that the aim of cartels and merger is monopoly profit, but there is another explanation that seems worth pursuing for two reasons. First, it avoids the inconsistency between the assumption of large numbers of competitors in the theory of competition and the result that collusion is manageable only with small numbers of competitors. In other words, the possibility of competition is no longer to be assumed but deduced. Second, it provides testable implications about the circumstances under which collusion will take place and the forms that collusion assumes, and these implications differ in some respects from those offered in the more familiar theory.

The strategy here is to make necessary and reasonable assumptions about the technology and demand of a market and then try to infer what will happen under a regime of competition and independent action. This leads very quickly to a well-known impasse in oligopoly and game theory, but it serves to illustrate that the problems actually faced by firms may be more complicated than the model of competition implies. I could present technical results on this point, but the first-time reader will probably get more out of an example. The proposed solution to the impasse is a cooperative equilibrium, and although I will not specify the allocation of returns in that equilibrium, I will propose that certain economic institutions-cartels, merged firms, tacit collusion (if it exists), and government regulation-may constitute such cooperative outcomes.

Suppose three mutual strangers are hailing cabs at a street corner, and all three want to get to the airport. Each is willing to pay $\$ 7$. Two (unregulated) cabs, each assumed to have capacity for two passengers, show up at the same time. Each cabbie is willing to drive to the airport for \$6 with either one or two passengers. The marginal cost of carrying the second passenger is zero, the three passengers are jointly willing to pay $\$ 21$, and the cost of two cabs is $\$ 12$. The optimal solution calls for both cabs to go, implying a net social gain of $\$ 9$.

One way to explore this situation is to set up a competitive algorithma set of rules that embody the notion of competition and independent action-and then trace the consequences. The purpose of this algorithm, it should be stressed, is not to offer a prediction of what will happen in such situations, but to illustrate that there is no competitive allocation of

will be preferred if $P-M<x(P-C)$ or $P-C<(M-C) /(1-x)$, where $P-C$ is the cartel margin and $M-C$ is the per unit cost penalty from merger. A law against cartels can be thought of as raising $C$ and lowering $x$. 
returns to cabbies and prospective passengers. Assume that cabbies propose fares, passengers can accept or reject those proposals, and that proposals are not binding until all are convinced that no alternative proposal offers a superior outcome. If one cabbie proposes a fare of $\$ 5.00$, the other would find it in his interest to offer, say, $\$ 4.50$. This competition would continue until the offers reached $\$ 3.00$, and one cabbie dropped out. The winner in this bidding contest could then raise his price to the profit-maximizing $\$ 7.00$ which would allocate seats among the customers. But this would pull the loser back into the market, returning us to the beginning.

Another way of illuminating the difficulty for competition, one that avoids what may be the counterintuitive notion of seemingly endless recontracting, is to focus on the returns available to passengers and cabbies. The obstacle to a competitive outcome is that while the "best" solution from the point of view of any two passengers and one cabbie provides the highest average returns available, all cabbies and all passengers cannot obtain these returns. For example, the maximum return available to the three passengers is $\$ 9$, or $\$ 3$ each. Equal returns to the passengers could come about if all three passengers bargain collectively, but any two always have an incentive to band together and hire an idle cab, assuring themselves as much as $\$ 4$ surplus each.

The difficulty posed in this example shows up under a wide range of cost and demand conditions and has been in the literature for at least fifty years. ${ }^{7}$ Jacob Viner was led by "pseudo-dynamics" similar to those in the

\footnotetext{
${ }^{7}$ More general theoretical statements of this issue, based on the theory of the core, appear in Lester G. Telser, Economic Theory and the Core (1978), ch. 2; William W. Sharkey, A Study of Markets Involving Increasing Returns and Uncertain Demand (1973) (unpublished Ph.D. dissertation, Univ. Chicago); and id., The Theory of Natural Monopoly (1983), ch. 6. Sharkey interprets the results in this last reference as an instance of "destructive competition." I trace some of the intellectual history of the problem of fixed costs in George Bittlingmayer, Decreasing Average Cost and Competition: A New Look at the Addyston Pipe Case, 25 J. Law \& Econ. 201, 204-10 (1982); and in id., Price Fixing and the Addyston Pipe Case, 5 Research in Law and Econ. 57, 122-23 nn.5-10 (1983). The integer problem can emerge because of uncertain and variable demand and because larger production units have lower average costs than smaller units beyond some minimal capacity that is "large" relative to the market. So, in the example above, if three passengers showed up together in every market period, cabs serving that street corner would have seats for three passengers, with average costs presumably no higher than for cabs with only two seats. With contestability, the price charged would result in revenues that just cover costs. On the other hand, if cabs with one seat had the same costs per passenger as larger cabs, all cabs could have one seat and there would be no integer problem regardless of how many passengers showed up. It is true that the integer problem disappears if plants have "flat-bottomed" average cost curves. William J. Baumol, John C. Panzar, \& Robert D. Willig, Contestable Markets and the Theory of Industry Structure 32-40 (1982), justify the use of this assumption by an appeal to the empirical results of Joe S. Bain, Economies of Scale, Concentration and Entry, 44 Am. Econ. Rev. 15 (1954), and findings presented in Scherer, supra note 3, ch.
} 
bargaining rounds described above to conclude that prices in an industry with U-shaped average cost curves would oscillate. ${ }^{8}$ Other results are also conceivable. The Cournot-Nash equilibrium calls for each cabbie to offer the number of seats that provides the most profit, acting under the assumption that the other driver does not react to the first driver's actions. Each driver would offer one seat. (If passengers were divisible, each would offer 1.49 seats.) Although this seems possible, it is hardly inevitable.

Instead of looking for a noncooperative or competitive equilibrium, it may be useful to think of this situation as one in which a cooperative solution can be employed. There are several possibilities. In the example here, the passengers could present a united front to the two cabbies and split the surplus between them. As an alternative, the cabbies could agree to charge $\$ 7$ per passenger and split the resulting profit of $\$ 9$ between them. The cabs could also merge. Yet another possibility calls for the city government to issue rate regulations, stipulating a fare of, say, $\$ 6$ per passenger. This would not determine a unique allocation, but if an arbitrary criterion (a cab's distance from the curb) is used to settle which cab takes two passengers and which takes one, it would prevent the bargaining impasse and result in an allocation that is as good as any other. In similar examples involving larger capacities and more prospective passengers, price regulation and essentially random assignments would result in roughly equal numbers of passengers in each cab.

The structure of the problem is not rich enough to determine what institutional arrangement will emerge, but it is clear that the transactions costs involved in various alternatives will have a major influence. ${ }^{9}$ The

\footnotetext{
4. However, these results refer to long-run economies, and they do not rule out by any means economies over a substantial range, the effect of which is to create "gaps" in the short-run supply curve. The possibility of flat-bottomed long-run average cost curves seems to me to be of limited relevance to the question whether the integer problem is important empirically for short-run equilibria. For a different picture of the nature of costs than is implied by the survivor principle, see J. Maurice Clark, Studies in the Economics of Overhead Costs (1923); and the survey by A. A. Walters, Production and Cost Functions, 31 Econometrica 1 (1963). Note that with uncertain demand and transportation costs, the implications of the survivor principle do not hold since it becomes economical to maintain small costly plants.

${ }^{8}$ Jacob Viner, Cost Curves and Supply Curves, in Readings in Price Theory 198, 212 (George J. Stigler \& Kenneth Boulding eds. 1952).

9 The importance of transactions costs in overcoming the problem of an empty core is noted in Ronald Coase's comment on Varouj A. Aivazian \& Jeffrey L. Callen, The Coase Theorem and the Empty Core, 24 J. Law \& Econ. 175 (1981). Aivazian and Callen present a bargaining situation similar to the one presented above. Both their case and mine have an empty core. They use the pedagogical device of successive contracts to illustrate that no competitive solution emerges, and they conclude that "the nonexistence of the core furnishes yet a further rationale for the existence of particular contractual arrangements." id. at
} 
turnover of passengers may be high, ruling out collusion among passengers. On the other hand, a small and stable population of cab drivers could allow successful self-regulation or merger. If joint action by passengers or cabbies failed, or if the resulting prices were in excess of costs, government might step in. Of course, government might interfere anyway, and there is no guarantee that interference on legitimate grounds would be better than the evil aimed at. So, while the problem generated by fixed costs can be thought of as creating a "natural monopoly," in the sense that independent action and the price system do not lead to the optimal result, it is not clear that the ideal solution calls for either one firm or government regulation.

This discussion can be interpreted in terms of the theory of the firm. When the problems of economic organization cannot be handled by the price system, the response is often the establishment of an organization that substitutes command for independence and the use of prices. This is what typically occurs within individual plants or production units, although the difficulty of using the price system in organizing production often leads firms to encompass more than one plant. But just as competition within prescribed limits encourages efficiency within a firm, cooperation can be useful among firms when the price system cannot ensure efficient outcomes. So, although efficient economic organization requires a mix of competition and cooperation, the two types of organization are not in one-to-one correspondence with markets and firms.

In keeping with this view, the difficulty associated with fixed costs can be thought of as one variety of market failure that requires a partial suppression of independence and the competitive mechanism. Agreements among plants, a type of self-regulation in other words, and merger are two ways of accomplishing this. Since individual discretion and responsibility in many aspects of a plant's operations may still be desirable even if fixed costs make a neoclassical competitive equilibrium impossible, the least-cost solution could be the formation of a horizontal agreement instead of a consolidated firm. In this respect a cartel resembles a franchise agreement, which also employs a combination of restriction and

181. I would add that arrangements not enforced by a court of law may also represent solutions to an empty core and that the relative costs of various arrangements will determine which one is used. As Coase observes: "While consideration of what would happen in a world of zero transactions costs can give us valuable insights, these insights are, in my view, without value except as steps on the way to the analysis of the real world of positive transaction costs." Ronald H. Coase, The Coase Theorem and the Empty Core: A Comment, 24 J. Law \& Econ. 183, 187 (1981). The distance between Coase and Aivazian and Callen may be less than their exchange implies. The difficulty illuminated by an empty core points to a genuine problem in the real world, but how this difficulty is resolved undoubtedly depends on particular circumstances. 
freedom. The analogy is even closer when the terms of operation of individual franchises are governed by all franchise holders acting collectively. Not surprisingly, professional sports leagues look like monopolistic cartels at first glance. The limits to exploitation from such cooperative agreements, it should go without saying, are determined by potential competition, and the possibility of buyers integrating vertically or acting jointly. ${ }^{10}$

The market failure story has the following implications for the turn-ofthe-century merger wave. In the absence of legal restrictions, firms preferred cartelization because this was the cheaper way of organizing their industries. This may be particularly true of cyclical industries where ordinary market frictions make it possible to recover costs during periods of high demand and in which the integer problem requires a cooperative effort only sporadically. However, when antitrust laws raised the costs of institutions that facilitated cooperation, horizontal merger often became the best available option. Sometimes firms also turned to vertical mergers since the market failure generated by fixed costs can be remedied by horizontal agreement, horizontal merger, long-term contracts (vertical price fixing in effect), or vertical merger, with the choice governed by the relevant costs and benefits.

The monopoly explanation and the market failure explanations differ in some but not all of their implications. Both predict collusion when the number of firms in the relevant market is small, but only if the cost savings from remaining a cartel outweigh the incremental gains in revenue available under single-firm monopoly. Otherwise, the firms would have been merged already. Given the apparently small diseconomies from merger implied by the survivor principle, this suggests, under the monopoly explanation, small monopoly gains from merger in those cases where firms chose to remain cartelized. The two explanations are also consistent with vertical mergers occurring in response to laws against cartels. Vertical mergers could occur under the monopoly explanation if the average (monopoly) price charged the buyer after the horizontal merger of a large part of the industry is higher than the average price charged previously by

${ }^{10}$ I present a more detailed account of these points in Bittlingmayer, Price Fixing and the Addyston Pipe Case, supra note 7, at 107-14. Another important difference between merger and price fixing is that price-fixing cartels can more easily add and drop members as demand conditions change. These conditions determine the appropriate scope of the cartel. Consequently, the extension of a merger beyond the firms involved in the preceding price-fixing cartel is consistent with the merger having the same aim as the cartel. This may occur if the cartel would have expanded at about the time of the merger in the absence of merger. Concerning the mergers of 1898-1902, it should also be pointed out that some firms may have been included in a consolidation if there was a substantial chance that antimerger legislation or Supreme Court decisions would have hampered merger in the future. 
the cartelized industry. (This is a minimum condition since vertical integration also entails costs.) Vertical mergers could occur under the market failure explanation if the vertical mergers provided the next best solution to market failure.

The two theories do diverge at several points. The monopoly theory makes no prediction about the influence of fixed costs on the probability of collusion ${ }^{11}$ (independent of its effects on the number of competitors), while the market failure explanation predicts that collusion is more likely the larger are each plant's fixed costs in relation to factors such as search costs and geographic dispersion. The monopoly theory also makes no prediction about the probability of collusion over the business cycle, while the market failure theory predicts that collusion is more likely in an industry downturn when the divergence between average and marginal cost is greatest. ${ }^{12}$ Finally, the monopoly explanation predicts that collusion is less likely the easier it is to enter the industry, while the market failure explanation predicts collusion even in industries with easy entry. ${ }^{13}$

\section{The Evolution of Antitrust Policy}

This section reviews developments in antitrust policy. ${ }^{14}$ Four points deserve emphasis: E. C. Knight made merger legal, at least in the minds

11 The ratio of fixed to variable costs is sometimes thought to be related to the likelihood of collusion, especially if the industry is operating short of capacity. It is argued that as the firm approaches bankruptcy, the benefits of price fixing (minimizing losses) increase, while the cost of price fixing stays the same. Granting this argument, consider the case where the price of the variable input increases and the industry faces inelastic demand. Although the ratio of fixed to variable costs has decreased, the divergence between fixed and variable costs has not, and the incentives to cartelization remain the same. It has also been argued that a greater divergence of fixed and variable costs makes collusion less likely because the incentives to cheat are greater.

12 See Peter Asch \& J. J. Seneca, Is Collusion Profitable? 58 Rev. Econ. and Statis. 1 (1976), for evidence that price-fixing firms are less successful than firms as a whole. It should be emphasized that while the divergence between average and marginal cost (as well as between average variable and marginal cost) is usually greater during a downturn, the probability of successful collusion also depends on the likelihood that firms can enforce the collusion, and this depends partly on the length of the expected horizon over which the potential colluders can be expected to work together. If some firms are likely to leave the industry during the next downturn, agreement is less likely. One implication is that collusion is more probable, other things equal, during the start of an upswing. See Lester G. Telser, A Theory of Self-enforcing Agreements, 53 J. Business 27 (1980), for an analysis of the incentives to collude under different expected horizons.

13 Perfectly frictionless entry and exit is compatible with the absence of a "sustainable" equilibrium. See Baumol, Panzar, \& Willig, supra note 7, especially ch. 2; and Sharkey, The Theory of Natural Monopoly, supra note 7, ch. 5.

${ }^{14}$ For general background on this topic see Hans B. Thorelli, The Federal Antitrust Policy (1955); and William Letwin, Law and Economic Policy in America (1965). Lester G. Telser, Genesis of the Sherman Act (December 1982) (Working Paper No. 24, Center Stud. Econ. and State, Univ. Chicago), presents an economic analysis of the origins of antitrust policy and railroad regulation. 
of many lawyers; judicial policy after Knight was directed at cartels and not merger; public agitation against the cartels may have added extra impetus to the merger wave through the many new state laws and federal legislative initiatives directed at the trusts in the years 1896-1900; and the nature of the assault on the trusts in the courts and legislatures was clear to the press and the legal profession.

The pervasive cartelization of the late 1800 s resulted in state antitrust legislation as early as the late 1880 s, but concern over the trust issue waxed and waned. ${ }^{15}$ The cycles of interest in controlling the trusts are evident in Table 1. For example, the Sherman Act of 1890 was preceded in 1889 by the passage of ten antitrust statutes and constitutional amendments at the state level. This legislative effort continued for two more years, but interest in the trust issue dropped off, perhaps because of the tariff and free silver issues, perhaps because the new legislation had to be tested in the courts.

When the Sherman Act was tested in 1895 in E.C. Knight ${ }^{16}$ the court upheld a consolidation involving the notorious Sugar Trust. This was viewed as a setback for antitrust policy. A renewed legislative effort began in 1895, which was slowed by the election year of 1896 and the Spanish-American War of 1898. This is reflected in the data on new statutes and amendments in Table 1. The number of mergers with capitalizations of $\$ 1$ million or more is also shown, and it certainly seems that mergers and antitrust legislation may have been linked, with coincidental increases occurring in the years 1888-92 and during the second half of the 1890s. (Data on U.K. mergers are also shown, and these will be discussed in the next section.)

One widespread interpretation of Knight was that merger was legal, although price fixing might not be. ${ }^{17}$ The origin of the view that merger

15 Cartels or trusts apparently existed in coal, oil, sugar, whiskey, cotton bagging, meat, cordage, lead, cottonseed oil, pig iron, bar iron, crucible steel, nails, stoves, oatmeal milling, drug retailing, coal dealing, ice, tiles, brewing, gunpowder, steel rails, wallpaper, railroading, candles, salt, barbed wire, and window frames and sashes. See Thorelli, supra note 14, at $74-79,158-59$, and Letwin, supra note 14 , at 109. This list is not exhaustive. Interestingly, it has sometimes been claimed that these cartels were never effective. Why then, one should ask, was cartelization tried again and again in so many different industries? Were there no net benefits?

16 United States v. E. C. Knight, 156 U.S. 1 (1898). The case involved the acquisition of four Philadelphia refineries by the American Sugar Refining Company (the "Sugar Trust"), which owned about 60 percent of sugar refining capacity nationwide. The history of the Sugar Trust is treated in Alfred S. Eichner, The Emergence of Oligopoly (1969). I thank Lester Telser for calling my attention to this book and to the emphasis it places on Knight as a cause of the merger wave.

${ }^{17}$ I will not presume to speak to the question of the correct legal interpretation of $E$. $C$. Knight. See Phillip Areeda \& Donald F. Turner, Antitrust Law (1978), at 230-32, and Posner \& Easterbrook, supra note 3, at 36-38, 96, for current interpretations of the case: 
TABLE 1

Antitrust Legislation and Industrial Mergers, 1885-1900

\begin{tabular}{lccc}
\hline \hline & $\begin{array}{c}\text { Statutes and } \\
\text { Constitutional } \\
\text { Amendments }\end{array}$ & $\begin{array}{c}\text { U.S. } \\
\text { Industrial } \\
\text { Mergers* }\end{array}$ & $\begin{array}{c}\text { U.K. } \\
\text { Manufacturing } \\
\text { Mergers }\end{array}$ \\
\hline 1885 & 0 & $\ldots$ & 6 \\
1886 & 0 & $\ldots$ & 10 \\
1887 & 1 & 8 & 15 \\
1888 & 0 & 3 & 19 \\
1889 & 10 & 12 & 27 \\
1890 & 8 & 13 & 31 \\
1891 & 6 & 17 & 17 \\
1892 & 2 & 12 & 7 \\
1893 & 3 & 7 & 11 \\
1894 & 1 & 6 & 26 \\
1895 & 6 & 5 & 44 \\
1896 & 2 & 7 & 52 \\
1897 & 14 & 20 & 73 \\
1898 & 2 & 87 & 62 \\
1899 & 11 & 42 & 63 \\
1900 & $\ldots$ & & 12 \\
\hline
\end{tabular}

SourCE.- Statutes and constitutional amendments are from 2 U.S. Industrial Commission, Trusts and Industrial Combinations, Statutes and Decisions of Federal, State and Territorial Law (1900). Industrial Mergers are from Jesse W. Markham, Survey of the Evidence and Findings on Mergers, in Business Concentration and Price Policy 141, 149 (1955). U.K. manufacturing mergers are from Leslie Hannah, Mergers in British Manufacturing Industry, 1880-1918, 26 Oxford Econ. Papers 1, 18 (1974).

*Number of U.S. industrial mergers with capitalizations of $\$ 1$ million or more.

was legal appears to have stemmed from the Court's narrow view of what constitutes interstate commerce. The Court had argued that "Congress did not attempt ... to limit and restrict the right of corporations created by the states or the citizens of the States in the acquisition, control, or disposition of property." 18 The interpretation that this language made merger legal was widely adopted in the law journals and other publications, ${ }^{19}$

Knight was followed in Hopkins v. United States, 171 U.S. 578 (1898) and Anderson v. United States, 171 U.S. 604 (1898), but it was avoided in later years. Id. at 38. Swift \& Co. v. United States, 196 U.S. 375 (1905), a merger case, is cited as the most important link in the chain by which manufacturing activity came to be included under the Sherman Act.

18 United States v. E. C. Knight, 156 U.S. 1, 16-17 (1895).

19 J. D. Forrest, Anti-Monopoly Legislation in the United States, 1 Am. J. Soc. 411, 424 (1896), claimed that the Sugar Trust decision "reserves to the United States the right to regulate trade and commerce only, and leaves the regulation of the acquisition and control of the property [that is, merger] to the states." Similar views appeared in the law journals. "While combinations in ... agricultural and manufacturing industries might have a great indirect effect on commerce, that was not sufficient for Congressional interference." Edward B. Whitney, Constitutional Questions under the Federal Anti-Trust Law, 7 Yale L. J. 285, 285 (1898). See also Lionel Norman, Legal Restraints on Modern Industrial Combinations and Monopolies in the United States, 23 Am. L. Rev. 449, 511 (1899); E. W. Huffcutt, 
by several attorneys general, ${ }^{20}$ and by the four dissenting justices in Northern Securities. ${ }^{21}$ Another part of Knight, which upheld the power of Congress to regulate "contracts to buy, sell or exchange goods to be transported among the several States," did appear to leave the door open to applying the Sherman Act against cartels. ${ }^{22}$

A firestorm of indignation, including a dozen new state laws, followed Knight. The state legislation may also have resulted from the impression the Court gave that it was up to the states to do something about monopoly. ${ }^{23}$ The first cartel case to reach the Supreme Court, Trans-Missouri,

Constitutional Aspects of the Federal Control of Corporations, 24 Am. L. Rev. 186, 195 (1900); and Daniel Ryan, The Combinations of Corporations, 10 Am. Lawyer 448, 449 (1902). Up until the eve of Northern Securities, it was possible to argue that "the agreement here [in Addyston] related to the method of disposing of the articles of manufacture, and not to the form of organization of the producer, and therefore, unlike the merger at issue in the Sugar Case, amounted to a regulation of interstate and foreign trade and commerce." William F. Dana, The Supreme Court and the Sherman Act, 16 Harv. L. Rev. 178, 181 (1903). Robert L. Raymond, The Federal Antitrust Act, 23 Harv. L. Rev. 353, 376-77 (1910), stresses the role of Knight in laying the foundation for the merger wave.

${ }^{20}$ See Judson Harmon, Letter from the Attorney General transmitting a reply to the House Resolution of January 7, 1896, Enforcement of the Laws against Trusts, Combinations, etc. H. R. Doc. No. 234, 64th Cong., 1st Sess. (February 8, 1896). "The Sherman antitrust law, as construed by the Supreme Court . . . does not apply to the most complete monopolies acquired by unlawful combination of concerns which are naturally competitive." Id. at 1-2. A letter from John W. Griggs, Attorney General in McKinley's administration, says that the mergers of 1898 and 1899 were like the sugar combination and therefore exempt from the antitrust laws. This letter was published in the New York Herald, according to Letwin, supra note 14, at 140. The effectiveness of the Sherman Act was in doubt even before Knight. See the discussion of Attorney General Olney's views in id. at 121-22; and Thorelli, supra note 14, at 383-93.

21 Northern Securities was filed as part of President Roosevelt's campaign to "control the trusts," and it was decided by a majority of five to four in a highly charged political atmosphere. Justice Holmes felt compelled to observe in his famous dissent that "great cases are called great, not by reason of their real importance in shaping the law of the future, but because of some accident of immediate overwhelming interest which appeals to the feelings and distorts the judgment." Northern Securities v. United States, 193 U.S. 197, 400 (1904). Holmes, id. at 404, emphasized that contracts in restraint of trade under common law "were contracts with strangers to the contractor's business, and the trade restrained was the contractor's own." Such contracts were illegal only if they "amounted to a monopoly." Combinations or conspiracies in restraint of trade "were combinations to keep strangers to the agreement out of the business." This, he claimed, was the ground for the decision in United States v. Joint-Traffic Ass'n, 171 U.S. 505 (1898). "To suppress competition in that way is one thing; to suppress it by fusion is another." 193 U.S. 197, 410. Relying on Knight, Justice White offered similar conclusions in his separate dissent to Northern Securities: "Whilst the power of Congress extended to commerce ... it did not embrace the ownership of stock in state corporations, because the products might subsequently become the subject of interstate commerce. The parallel between the two cases [Knight and Northern Securities] is complete. . . . the ownership of the stock in the corporation was not itself commerce." 193 U.S. 197, 381.

22 United States v. E. C. Knight, 156 U.S. 1, 13 (1895).

${ }^{23} \mathrm{Id}$. at 11. 
was decided in March of 1897, within two or three months of the flurry of new state legislation, and popular unrest may explain why five justices thought the Sherman Act should be applied to railroads despite the fact that railroad regulation and, in particular, railroad pooling, had been addressed separately in the Act to Regulate Commerce. The majority said clearly that similar agreements between industrial firms would also be held illegal. ${ }^{24}$

The decision had the effect of "completely unsettling the values of railroad securities on the Stock Exchange," according to the Commercial and Financial Chronicle. ${ }^{25}$ The Chronicle also credited the Court's decision with hampering recovery from the 1896 recession. ${ }^{26}$ Similar consequences might have been expected in the October 1898 Joint-Traffic decision, which involved a railroad agreement specifically designed to pass antitrust muster, but which the railroads also lost. This case had a smaller effect on stock prices though, maybe because the decision was expected, maybe because, as the Chronicle suggested, legislation to permit pooling was expected. ${ }^{27}$

In the meantime the judicial onslaught was extended directly to industrial cartels in the appeals court decision in Addyston, handed down in February 1898. The price-fixing cartel of six manufacturers of cast iron pipe was found to be in violation of the Sherman Act. The opinion in this case is now often considered a classic in the development of the per se rule against price fixing, and was written by William Howard Taft, then a judge for the sixth circuit. However, Taft was still obliged to address the implications of Knight, and he seemingly left open the door to merger. ${ }^{28}$

Although the Chronicle was eager to put the best possible interpretation on what Taft said concerning the illegality of price-fixing agreements, noting that the "Cast Iron Pipe Trust seems to have been obnoxious in many ways," it was forced to concede that "there is a part of the dictum of the Court which seems to be of wider application, and which has been given special prominence in the newspapers.",29

The trade publication for the iron, steel, and hardware industry, Iron

\footnotetext{
${ }^{24}$ United States v. Trans-Missouri, 166 U.S. 290, 324-25 (1897).

${ }^{25}$ Commercial and Financial Chronicle, March 27, 1897, at 586.

${ }^{26}$ Id. April 24, 1897, at 774. Whether or not this was true, the Chronicle's comments show that the decision was apparently not obscure or lightly regarded.

${ }^{27}$ Commercial and Financial Chronicle, October 29, 1898, at 871.

${ }^{28}$ United States v. Addyston Pipe, 85 Fed. 271, 296-98 (1898). "The subject matter of the restraint here was not articles of merchandise or their manufacture [as in Knight], but contracts for sale of such articles to be delivered across state lines." Id. at 298. See also the Supreme Court's discussion of this point, Addyston Pipe v. U.S., 175 U.S. 211, 240 (1899).

29 Commercial and Financial Chronicle, February 19, 1898, at 362.
} 
Age, ran a full-column editorial on the decision and concluded that merger might now replace price fixing. "The new decision is one which may gravely affect some of the arrangements now in force among manufacturers in different lines, in which some control over prices is sought by concerns otherwise acting independently in the conduct of their business. At first sight it looks as though this decision must drive them to actual consolidation, which is really more apt to be prejudicial to public interests than the losses and temporary agreements which it condemns." $30 \mathrm{~A}$ month later Iron Age reported that "quite a number of meetings of manufacturers have been held during the past week all looking to some scheme to take off the keen edge of unbridled competition.,"31

Developments at lower levels of jurisdiction, aside from Addyston, may also have had an influence. For example, Standard Oil, this country's best-known trust, came under renewed attack in November of 1897 in Ohio ${ }^{32}$ and in a private antitrust suit filed the following month by the United States Pipe Line Company of Pennsylvania. ${ }^{33}$ The general trend was summarized by a speaker in 1899 at the Chicago antitrust conference, ${ }^{34}$ and the increased public concern with the trust question is clearly reflected in the great volume of literature that appeared even before anyone was aware that there was a merger wave. ${ }^{35}$

All that said, the fact remains that only seven federal cases involving

${ }^{30}$ Iron Age, February 17, 1898, at 18. Whitney, supra note 19, at 290, pointed out that "Justice Harlan of the Supreme Court (one of the majority of the Court in the TransMissouri case) concurred" in Taft's opinion.

${ }^{31}$ Iron Age, March 17, 1898, at 30. The widespread breakdown of cartel agreements in 1896 and 1897, that is, even before Trans-Missouri, has been noted, most recently in a forthcoming book by Naomi Lamoreaux, The Great Merger Movement in American Business, 1895-1904. This book attributes the failure of price-fixing cartels and the ensuing mergers to the recession of 1896-97. Another possibility is that a substantial increase in the likelihood of adverse antitrust policy made it more difficult for firms to collude because the threat of withdrawing cooperation in the future was less credible. This line of reasoning extends to other events, such as William Jennings Bryan's candidacy, that introduced economic uncertainty.

${ }^{32}$ Lewis Haney, Business Organization and Combination 215 (1913).

${ }^{33}$ Iron Age, December 30, 1897, at 23.

${ }^{34}$ Chicago Conference on Trusts 528-29 (Franklin H. Head ed. 1900).

${ }^{35}$ See Thorelli, supra note 14, at 329-43, for an overview of popular opinion on the trust issue. Charles J. Bullock, "Trust Literature: A Survey and Criticism," 15 Q. J. Econ. 167 (1901), provides a guide to the immense volume of the 1890s professional literature on trusts. Several legal books appearing on the trust issue were stimulated by the court cases, not the merger wave, which had barely begun. See Andrew J. Hirschl, Combination, Consolidation and Succession of Corporations (1896); Albert Stickney, State Control of Trade and Commerce by National or State Authority (1897); and Frederick H. Cooke, Law of Trade and Labor Combinations (1898). 
horizontal agreements were instituted in the years $1895-99 .{ }^{36}$ Could these cases have caused the merger of a large fraction of U.S. manfacturing? Given the hundreds of cartels that apparently operated in the 1890 s, the probability of conviction (post hoc) was very small. Still, one could argue that the cost of an antitrust case is greater than the probability of getting caught times the fine. Legal costs, the opportunity costs of managers, and the implicit costs of bad publicity (more harassment in the press and from government) also have to be reckoned with. But this does not add much, given the small number of cases.

It is also true that expected costs are not the same thing as realized costs. "Everything that is, was expected," is not a valid implication of rational expectations. The trusts were a lively political issue, and if it is surprising today that antitrust enforcement got off to such a slow start in the 1890 s, it is possible that the slow start may have been surprising at the time. ${ }^{37}$

Another important feature of the uncertain political climate is that it decreases the horizon over which a cartel can be expected to operate. Since a cartel is a self-enforcing contract, and since a breach of a selfenforcing contract is more likely the shorter the expected horizon (because the losses from noncooperation are less), the antitrust agitation would imply a greater tendency for cartels to break down even in the absence of large scale convictions.

Probably the best evidence that business chafed under the prohibition against cartels is that it made continual efforts to have the Sherman Act amended. The trade press and corporation lawyers fulminated against the Sherman Act, and several attempts were made in the years 1900-1910 to change the law. For example, considerable effort was made on behalf of a bill "to legalize contracts and agreements not in unreasonable restraint of trade or commerce." 38

${ }^{36}$ Richard A. Posner, A Statistical Study of Antitrust Enforcement, 13 J. Law \& Econ. 365 (1970), at 366, Table 1.

37 The Antitrust Division was established in 1903 and given a half-million dollar appropriation. See Thorelli, supra note 14 , at 537.

${ }^{38}$ Bill S. 6331 to Legalize Contracts and Agreements Not in Unreasonable Restraint of Trade of Commerce: Hearings Before the Subcomm. of the Senate Comm. on the Judiciary. 60th Cong., 1st Sess. (April 1908). Andrew Carnegie, retired and clipping coupons from U.S. Steel bonds (he had not wanted stock when he sold his company to the U.S. Steel consolidation), testified on behalf of legislation to allow "reasonable" price fixing. The changed status of price fixing, despite the paucity of prosecutions, is reflected in Carnegie's remark that "men of the highest standing in the past thought they did no wrong and sought no concealment." Congressional statement quoted in Industrial Combinations and Trusts 557, 559 (W. S. Stevens ed. 1914). For a history of early attempts to change the Sherman Act, see Letwin, supra note 14, chs. 6-7. 
IV. Mergers in the United States and United Kingdom, 1890-1905

Table 2 shows the remarkable increase in mergers that occurred in the late 1890s. The number of firms absorbed by merger in manufacturing and mining rose from sixty-nine to 303 between 1897 and 1898, and rose further to 1,208 in 1899. Merger disappearances in primary metals and metal products rose even more sharply over the same period. Another important point is that consolidation of several firms, rather than piecemeal acquisition, accounted for roughly 90 percent of all firm disappearances until 1902.

Firm disappearances count large and small firms alike. A better way to get an idea of the scope of the merger wave is to look at total merger capitalizations, although this involves substantial double counting when firms are formed in a series of mergers. Based on capitalization values, more than half of the merger movement in mining and manufacturing during the peak years 1899-1901 can be accounted for by mergers in metal industries. The merger movement as a whole seems to have encompassed between one-fourth and one-half of U.S. industry. ${ }^{39}$

One issue that arises in connection with the U.S. mergers at the turn of the century is that Great Britain had a merger wave at about the same time. In fact, it is possible to show that the two are related statistically. This suggests the possibility of a joint cause, apparently confined to the United States and United Kingdom. It is not clear though if the two merger movements are in fact part of the same phenomenon since there are some noteworthy differences and since statistical correlations are never enough to establish causation. A plausible joint cause has so far proved elusive.

Table 3 presents comparable data for U.S. and British mergers for the years 1895-1905. Comprehensive U.S. data go back only to 1895. Comparable U.S. and U.K. data for earlier years covering the number of manufacturing mergers, with the U.S. data based on a less authoritative source, are shown in Table 1. Although it is clear that there was an increase in

\footnotetext{
39 The 1898-1902 capitalizations amounted to 53 percent of the value of all manufacturing and mining operations. However, this probably overstates the extent of the merger movement because the same property was often involved in several successive mergers. See Yale Brozen, Mergers in Perspective 6-8 (1982). According to one estimate based on incomplete merger data, about 15 percent of the total number of plants and employees in manufacturing in 1900 were involved in mergers over the years 1887-1904. See Jesse W. Markham, Survey of the Evidence and Findings on Mergers, in Business Concentration and Price Policy: A Report of the National Bureau of Economic Research 141, 152 (1955). According to another estimate, 318 industrial combinations formed in the years 1897-1904 controlled 40 percent of U.S. manufacturing capital. See Donald Dewey, Monopoly in Economics and Law 49 (1959).
} 


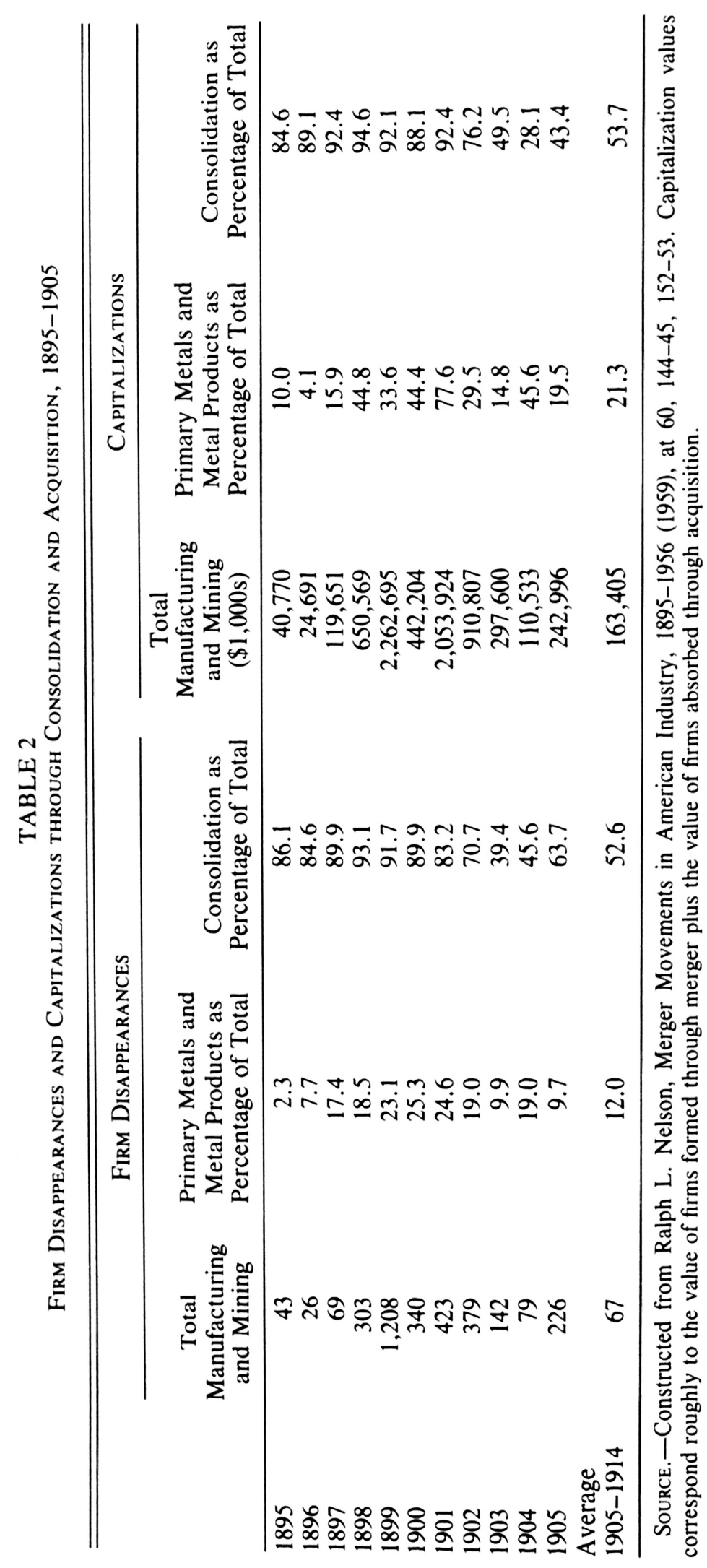




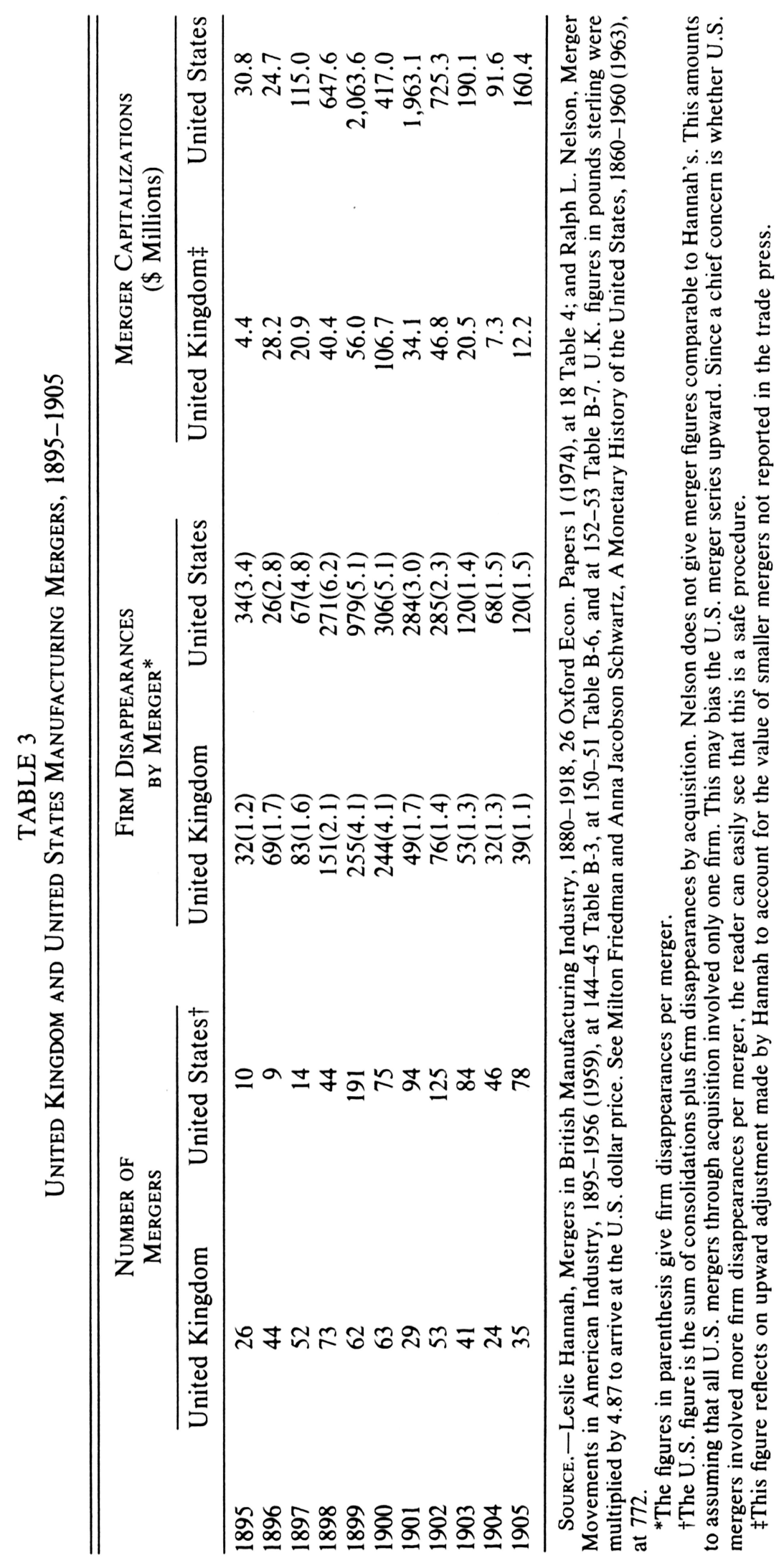


mergers in both countries in the late 1890s, there are several notable differences. First, the United States seems to have had a larger wave, and a sharper increase. (Although the U.S. data go back only to 1895, I will extend my range for the U.K. data to 1890 in the comparisons of U.S. and U.K. data that follow to allow for the possibility that the U.K. "wave" started earlier.) The peak U.K. value for mergers (seventy-three) is ten times the lowest value (seven in 1892), while the U.S. peak (191) is twenty times the lowest value (nine). Similarly, the highest value for U.K. firm disappearances, which occurs in 1899 , is twenty-three times the lowest value of eleven, which occurred in 1893; in the U.S. the highest and lowest values are 979 and twenty-six, implying a thirty-eight-fold increase. Since the U.S. series is truncated at 1895, these comparisons probably understate the differences. Only in capitalizations are the British increases greater than those for the United States: an increase of 109-fold from 1893 to 1900 , compared to a U.S. increase by a factor of sixty-six from 1896 to 1899 . Note though that the average yearly increase is about the same. Second, U.S. mergers involved more firms per merger, although this difference narrowed after Northern Securities was filed. Third, the U.S. mergers, although roughly equal in number to U.K. mergers, apparently involved much larger firms and quite likely more successive mergers in the same industry. Cumulative capitalizations in the U.S. were seventeen times U.K. capitalizations. In one year, 1901, capitalizations were fifty-eight times as great. One reason for this may be that U.S. mergers were concentrated in metal and metal fabricating, where average plant size tends to be greater. Twenty-six percent of the 2,782 U.S. firm disappearances from 1895 to 1909 occurred in this industry, while only 11 percent of the 1,428 U.K. disappearances took place there. Nearly 30 percent of the U.K. disappearances took place in textiles, and another 28 percent took place in food and drink manufacture (chiefly brewing), together accounting for nearly 60 percent of British firm disappearances. In contrast, 22 percent of U.S. mergers took place in textiles, and less than 4 percent took place in food (and drink) products. Although comparable U.K. data are unavailable, it should be noted that textile capitalizations account for less than 1 percent of total U.S. manufacturing capitalizations for 1895-1904, while primary metals alone account for 41 percent. ${ }^{40}$

Although these comparisons suggest that the U.S. merger wave was larger and more pronounced, and that it tended to be relatively stronger in

\footnotetext{
40 Data are from Leslie Hannah, Mergers in British Manufacturing Industry, 1880-1918, 26 Oxford Econ. Papers 1, 18 (1974); and Ralph L. Nelson, Merger Movements in American Industry, 1895-1956 (1959), at 144-53. These comparisons are meant only to suggest the differences involved. A more formal investigation would require information on the assets and numbers of firms in various British and U.S. industries.
} 
certain industries, there is still the question why mergers occurred in both countries. It can be shown that merger time series data for the years 18951918 for the United States and United Kingdom are related. ${ }^{41}$ For example, there is a correlation between year-to-year changes of U.K. firm disappearances and year-to-year changes of U.S. firm disappearances by consolidation ( $r=.38$, which is significant at the 10 percent level for twenty-three observations). But what should be done with this empirical finding? Granting the fact of a statistical relationship, I would not want to insist on a single explanation. Well-worn but valid arguments force me to observe that such results could be spurious, ${ }^{42}$ and we have precious little in the way of a plausible common explanation. Under these circumstances, investigating the two movements one at a time strikes me as a defensible research strategy.

In examining the data we should also look to see whether merger activity is inconsistent with the timing of key antitrust decisions. Table 4 presents quarterly merger figures and some key events in antitrust history for the years 1895-1900. Bold-face numbers show where the quarterly merger figures reached a new high (beginning with the third quarter of 1895). Thus E. C. Knight was followed by three successive quarters of increased merger activity, consistent with the view that it did signal that merger was legal under the Sherman Act. Only twelve firm disappearances occurred between this mini-wave and the first quarter of 1897, when Trans-Missouri was announced and many state antitrust laws were passed. After a one-quarter lull, merger activity increased to unprecedented levels, then decreased just before the Addyston appeals decision, only to increase when the decision was announced. After another onequarter lull, merger activity increased steadily until early 1899 and remained above pre-1897 levels until the end of 1900 .

It would be unrealistic to expect data of this kind to show unambiguously that Supreme Court cases caused mergers, since the lags could be variable and the cases are only a proxy for actual expected policy. Interpretations of court doctrine by prominent authorities, initiatives to amend

${ }^{41}$ These are the years for which the data cited supra note 40 overlap.

${ }^{42}$ For example, antitrust enforcement may be procyclical. This seems reasonable since landmarks in more stringent antitrust policy such as the passage of the Sherman Act (1890), the per se rule (1897-99), Northern Securities, the tobacco and oil dissolutions (1911), and the reestablishment of the per se rule in United States v. Trenton Potteries, 273 U.S. 392 (1927), occurred during periods of expansion. Backsliding, as in E. C. Knight, United States v. United States Steel, 251 U.S. 417 (1920), Appalachian Coals v. United States, 288 U.S. 344 (1933), and the NRA cartelizations, occurred in periods of contraction. The less volatile U.K. series may have been the response to other developments that were also related to business activity. The business cycles of the United States and the United Kingdom were of course related, in part because both were on the gold standard. 
TABLE 4

Quarterly Merger Statistics and Antitrust Policy, 1895-1900

\begin{tabular}{|c|c|c|c|}
\hline $\begin{array}{l}\text { Year and } \\
\text { Quarter }\end{array}$ & $\begin{array}{c}\text { Manufacturing } \\
\text { Merger Capitalizations } \\
\text { (\$ Millions) }\end{array}$ & $\begin{array}{l}\text { Quarterly Firm } \\
\text { Disappearances }\end{array}$ & Events \\
\hline 1895:I & 1.0 & 3 & E.C. Knight \\
\hline II & 10.4 & 14 & \\
\hline III & 14.5 & 24 & \\
\hline IV & .6 & 1 & \\
\hline 1896:I & 6.1 & 3 & \\
\hline II & 4.5 & 7 & \\
\hline III & 0 & 0 & Election campaign of 1896 \\
\hline IV & 1.3 & 1 & \\
\hline 1897:I & 10.0 & 8 & State Laws and Trans- \\
\hline II & 0 & 0 & Missouri \\
\hline III & 81.6 & 38 & \\
\hline IV & 10.3 & 17 & \\
\hline 1898:I & 167.6 & 132 & Addyston (Appeals Court) \\
\hline II & 44.7 & 64 & Spanish-American War \\
\hline III & 209.3 & 19 & \\
\hline IV & 212.3 & 76 & Joint Traffic \\
\hline 1899:I & 862.4 & 410 & \\
\hline II & 522.4 & 271 & \\
\hline III & 373.4 & 316 & \\
\hline IV & 112.9 & 128 & Addyston (Supreme Court) \\
\hline 1900:I & 149.9 & 147 & \\
\hline II & 126.9 & 55 & \\
\hline III & 98.3 & 60 & \\
\hline IV & 11.8 & 53 & \\
\hline
\end{tabular}

SourCE.-Ralph L. Nelson, Merger Movements in American Industry, 1895-1956 (1959), at 139 Tables B-1, 164 C-7; and 1 U.S. Courts, Federal Antitrust Decisions (1912).

Note.-These figures do not agree with Nelson's annual statistics because he could not assign all mergers to a specific quarter. Beginning with 1895: III, boldface numerals indicate a new high.

legislation, and declarations of war are all factors that could make mergers occur one or two quarters sooner or later. However, I would emphasize that increases in mergers occurred within one or two quarters or at the same time as the crucial cases, and not before or after very long delays. Statistical tests in Section VII, which use a longer time series for mergers, confirm the empirical connection between changes in antitrust policy and merger in a more formal way.

\section{Some Case Studies of Merger}

Two well-studied industries, railroading and iron and steel, provide concrete instances in which merger followed extensive cartelization after the court decisions of 1897 and 1898. In several industries antitrust charges preceded merger, and in at least two cases we know of, the firms 
merged after looser arrangements were ruled out on the basis of legal advice.

\section{A. Iron and Steel}

Cartel agreements in iron and steel existed in pig iron, steel billets, steel rails, structural steel, steel plate, nails and wire, and numerous other products. ${ }^{43}$ U.S. Steel was formed in 1901 as a holding company organized under the laws of New Jersey. Its three major components were the three largest iron and steel producers in the United States: the Carnegie Company, the Federal Steel Company, and the National Steel Company. U.S. Steel also assumed control of a number of producers of finished goods that dominated their fields, including the American Tin Plate Company, the American Steel and Wire Company, and the National Tube Company, and it absorbed substantial transportation and mining facilities that had previously been independent firms. In turn, two of the major steel companies that became part of U.S. Steel, Federal and National Steel, were themselves formed through mergers in 1898, as were many of the producers of finished products. For example, the American Steel and Wire Company was organized in April of 1898 out of fourteen mills, and the successor consolidation, with twenty-nine plants in 1900, owned nearly every wire, wire rod, and wire nail plant in the United States. The Wire Nail Association had cartelized this industry in the mid-1890s. ${ }^{44}$

The connection between price fixing and merger in the steel industry can probably be explored at greater length, but the major developments in this industry certainly make it reasonable to infer that merger performed some of the function of the abandoned cartels. The mergers also occurred at just the right time to raise the suspicion that they were a response to legal developments. In addition, iron and steel provides a classic industry where production takes place under fixed costs and where transportation costs were probably high enough to create regional markets with small numbers of competitors. ${ }^{45}$

43 This sketch of developments in iron and steel is based on Eliot Jones, The Trust Problem in the United States 186 (1921). Charles Schwab, who had been Andrew Carnegie's protégé, and who was later president of U.S. Steel and Bethlehem Steel, was asked while testifying before the Industrial Commission whether pooling arangements had existed before the formation of U.S. Steel in 1901. "Yes," he replied, "in all lines of business, not only in steel, but in everything else. There were similar agreements, known as joint arrangements to maintain prices. They have existed in all lines of business as long as I can remember." Quoted in Haney, supra note 32, at 146.

${ }^{44}$ Nails and Wire in 1898, Iron Age, January 5, 1899, at 41.

45 This is illustrated in Bittlingmayer, Price Fixing and the Addyston Pipe Case, supra note 7, at 70-72. Cast iron pipe was transported at the same rate as pig iron. The f.o.b. price of pig iron varied between $\$ 6.00$ and $\$ 12.00$ per ton in the $1890 \mathrm{~s}$, and the cost of transportation in 1893 from the southern producing district in Alabama to Cincinnati (400 miles) was $\$ 2.75$ per ton, or as much as 31 percent of the delivered price. 


\section{B. Railroading}

Railroading provides another instance in which production is carried out with substantial fixed expenses, and in which the relevant market (transportation between two points) frequently has few competitors. In addition, railroad cartels were the focus of the first two significant cartel cases to reach the Supreme Court. ${ }^{46}$

Railroads had passed through trying times in the early and mid-1890s. Although the 1887 Act to Regulate Commerce had prohibited pooling (apparently to satisfy one senator and on an experimental basis), ${ }^{47}$ pooling agreements continued to be prevalent. These agreements faltered in the mid-1890s however, possibly because of their shadowy legal status. Two major recessions also occurred in that decade, and some combination of low freight rates and low freight volume caused many railroads to go into receivership. Although some railroad consolidations had been undertaken in the mid-1890s, their number increased sharply after the Trans-Missouri and Joint Traffic decisions. This is evident in the data on mergers for twelve-month periods ending in June that are displayed in Table 5. Mergers increased substantially in 1897, following Trans-Missouri, and declined while Joint Traffic wound its way to the Supreme Court. This case was decided in October of 1898 , and mergers and consolidations increased for the period July 1898-1899. Over the next twelve months, ending June 1900, mergers increased to a new high.

The effect of these mergers is also reflected in the growth of class 1 railroads-those with 1,000 miles or more of track, also shown in Table 5. The number of class 1 railroads increased from forty-four to fifty-one (or 16 percent) between June 1899 and June 1902. In addition, the larger 23 percent increase in class 1 mileage suggests that a good deal of the overall growth came from existing class 1 roads. The percentage of railroad mileage under class 1 control increased from 57 percent in 1899 to 65 percent in 1902.

Merger was only one way of achieving coordinated operation of different railroads. Another method, pioneered by Standard Oil and adopted by the railroads in 1899 , was the "community of interest," which formed the basis for the "great systems" associated with Morgan, Gould, Harriman, and others. ${ }^{48}$

${ }^{46}$ I thank Lester Telser for asking, after reading the first draft of this paper, what happened in railroading.

4719 U.S. Industrial Commission, Final Report, House Doc. No. 380, 57th Cong., 2d Sess. (1902), at 337-38. (This volume bears the title Transportation and was written by William Z. Ripley.)

${ }^{48}$ Haney, supra note 32 , at 205-7. Haney, id. at 246-48, claims that leasing was yet 


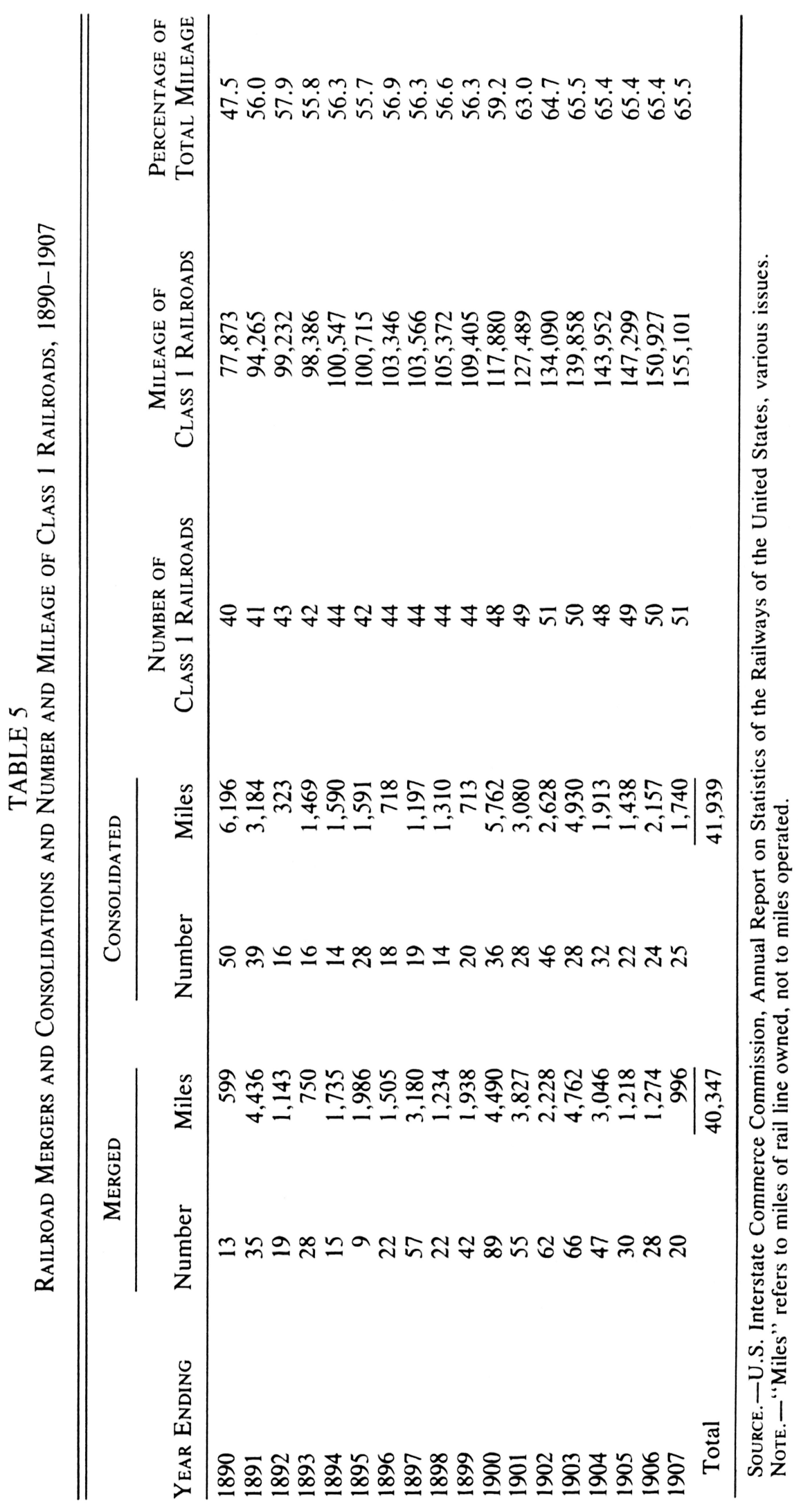


These developments are consistent with the view that the Supreme Court drove railroads to other forms of joint control, although not always merger. Writing in 1902 for the Industrial Commission, William Ripley claimed that a less formal organization took the place of the Joint Traffic Association. "It continues to perform many functions of a cooperative character, and has not occasioned serious complaints on the part of shippers. There seems to be some sort of agreement between the lines by which harmony is engendered." 49 Harmony among members of the Trans-Missouri Freight Association was apparently sought by a community of interest. ${ }^{50}$

There seem to be two factors that offset the influence of the 1897 and 1898 decisions. The prohibition of pooling and the erosion of Interstate Commerce Commission powers in the early $1890 \mathrm{~s}^{51}$ probably stimulated some consolidations among railroads even before these court decisions were made. Consistent with this, Table 5 shows that an annual average of about 2 percent of U.S. mileage was merged or consolidated over the years 1890-96. However, serious legislative efforts were made to permit pooling and to reform the regulation of railroads in other ways in the late 1890 s and ensuing years. ${ }^{52}$ The overall effect of these two influences was probably to soften the impact of the two railroad cases.

\section{Shoe Machinery and Explosives}

In at least two instances we have evidence that legal advice regarding the illegality of looser forms of organization played a role in inducing firms to merge. United Sho $e^{53}$ concerned a consolidation conceived in 1898 and undertaken in order to evade the antitrust laws, according to testimony of a key figure. This was noted in a dissent by Justice Clarke, who also thought that Trans-Missouri had suggested that there might be legal problems. ${ }^{54}$

another method used to obtain control of a railroad. For more recent accounts of the development of the "Great Systems," see Alfred D. Chandler, The Visible Hand 172-74 (1977), and id., The United States: Seedbed of Managerial Capitalism 27, 38 (1980). According to a table compiled in 1901 by the Common Carrier, a trade journal, more than half of U.S. mileage was under the control of six "financial interests," of which four had at least 18,000 miles of track each. U.S. Industrial Commission, supra note 47, at 307-8. The United States had approximately 200,000 miles of railway in 1900 .

${ }^{49}$ U.S. Industrial Commission, supra note 47 , at 335.

${ }^{50} \mathrm{Id}$. at 336.

${ }^{51}$ Gabriel Kolko, Railroads and Regulation, 1877-1916 (1965), ch. 4.

${ }^{52}$ Id. ch. 5.

53 United States v. United Shoe Machinery, 247 U.S. 32 (1918).

${ }^{54}$ E. P. Howe of the Goodyear Company, and a lawyer, is quoted as objecting to a 
The antitrust laws were also mentioned in connection with the consolidation of Du Pont properties in 1903. Following the acquisition of several explosives plants, the executive committee of the Du Pont Company addressed the question of firm organization. The decisive factor, which was stressed by both lawyers who had been asked for advice, was that the existing arrangements, involving both cartel agreements and distinct subsidiaries, were "absolutely illegal."

Walker [one of the lawyers hired by Du Pont] particularly stressed that the Supreme Court, in its interpretations of the Sherman Antitrust Act, had opposed practices restricting production. On the other hand, Walker continued, "the restrictions placed on large aggregations of capital are not intended to prevent legitimate expansion of business, however large." The Chicago lawyer pointed to the E. C. Knight case of 1895 in which the Court found the American Sugar Company not guilty, even though it controlled $90 \%$ of the sugar production in the United States, because it had "no intermediate selling company or corporation and no exclusive sales contracts." Then in the Addyston Pipe and Steel case of 1899 the Court dissolved the contract among six companies that set up exclusive marketing areas for each of the six firms. Moreover, Walker was certain that in the Northern Securities case then pending before the Supreme Court, the use of a holding company to restrain production or control competition would be declared illegal. "I would avoid," he concluded, "all 'entangling alliances' or contracts, but stand simply on the legality of your incorporation and the management and conduct of its corporate business. ${ }^{55}$

These legal views illustrate several plausible consequences of the Supreme Court's antitrust decisions. First Knight does seem to have been thought of as sanctioning merger. Second, Addyston appears to have been thought of as more than a simple price-fixing case. One lawyer apparently thought that it outlawed exclusive territories even in the case where the firms might be subsidiaries of the same holding company. It seems strange today, but a turn-of-the-century lawyer probably saw a close connection between price-fixing agreements and other sorts of business relations. This is reflected in the legal literature,${ }^{56}$ as well as in Taft's

\footnotetext{
"harmonious arrangement" or "working agreement" because "I had a sort of indefinite fear that it might be deemed to be a combination in restraint of trade. . . I had an indefinite fear that if the two companies remained separate but, for instance, had a joint factory and joint branch offices, there might be something in the way of restraint of trade. I insisted, for that reason, that there should be a complete merger and consolidation." Quoted in United States v. United Shoe Machinery, 247 U.S. 32, 77 (1918).

55 Alfred D. Chandler \& Stephen Salsbury, Pierre S. Du Pont and the Making of the Modern Corporation, 112-13 (1971). I thank Alfred Chandler for directing me to this passage in response to an inquiry. Haney, supra note 32, at 244-45, summarizes the substitution of complete merger for looser forms and claims that the aim was in part to "gain a stronger legal position." Similarly, Haney, id. at 243, attributes the 1904 consolidation in the tobacco industry to concern about vulnerability to antitrust.

${ }^{56}$ See the works by Hirschl, Stickney, and Cooke, supra note 35.
} 
opinion in Addyston, which takes great pains to distinguish cartel agreements from other arrangements between firms. ${ }^{57}$ Third, this account shows that Northern Securities influenced how lawyers thought about the legality of the holding company, even, as here, before the decision was handed down.

\section{Cotton Oil, Sugar, Cast Iron Pipe, Oil Refining, and Meat Packing}

In another important class of mergers consolidation followed closely on the heels of antitrust action directed against specific cartels. At least five mergers fit this description: the reorganization in 1889 of the Cotton Oil Trust, ${ }^{58}$ the acquisition in 1892 of major competitors by the American Sugar Refining Company, ${ }^{59}$ the merger in 1898 of the defendants in Addyston Pipe ${ }^{60}$ the formation in 1899 of the Standard Oil holding company, ${ }^{61}$ and the creation in 1902 of National Packing. ${ }^{62}$

\section{E. The View of an Important Promoter}

Charles R. Flint was a leading promoter of turn-of-the-century mergers who mentioned the antitrust laws as an important cause of the consolidations. His observations deserve some attention, partly because his analysis of the gains and losses from large firms has the ring of a familiar economic argument. The drawback to the merger of several industrial firms, Flint might say today, is that it creates a principal-agent problem.

While the financial interest of the individual entrusted with the local management of the sub-company or plant is as large as before, his percentage of interest, owing to its being merged with other concerns, is very much less, and the inducement of exertion and economy is not as large as before. In the export and import business we are able clearly to divide our business into departments, according to countries or staples, interesting each head in the department he manages. Here

57 United States v. Addyston, 85 Fed. 271, 281-83 (6th Cir. 1898). The distinction seems to have been hard to draw; Taft's test for distinguishing good from bad restraints is termed "circular" in Posner \& Easterbrook, supra note 3, at 110. The possibility that the cartels may have been viewed as part of a larger class of agreements raises the question whether other sorts of agreements besides classic cartels may have been converted to merged firms because of concern about antitrust. Although not converted through merger, General Electric and Westinghouse had an agreement on the joint use of patents. See Thorelli, supra note 14 , at 271 .

58 Thorelli, supra note 14 , at 79.

59 Eichner, supra note 16, at 6.

60 Bittlingmayer, Price Fixing and the Addyston Pipe Case, supra note 7, at 85.

61 Haney, supra note 32, at 215.

622 Simon N. Whitney, Antitrust Policies 33 (1958). 
the departments are independent. But in the case of the consolidation of manufacturing operations, such an arrangement is very difficult, as there is likely to be a conflict of interest, owing to their interdependence. It is therefore undesirable to have any individual interested otherwise than in the common result. ${ }^{63}$

Flint mentioned several advantages to merger against which this problem had to be weighed. Among the more or less innocuous gains are discounts on raw materials, the specialization of plants, the regulation of product diversity, economies of distribution, and inventory savings. To this he added the prevention of price cutting and the "demoralization" of business that occurs during business downturns. "Under industrial combination, however, each concern obtains a fair share of the reduced prices; and the contraction of business is conducted with the orderliness of a retreat of a well-disciplined army." $" 64$

Flint did not think merger was the ideal solution, however, and, as the quotation above shows, he seems to have preferred a looser form that preserved some of the independence of individual plants while controlling prices. In testimony before the Industrial Commission, Flint was asked what sort of trust legislation he favored. He replied that he thought it was difficult to draft beneficial legislation and that the existing antitrust laws had tended to force mergers.

My idea is that affairs of trade are best regulated by natural laws. It is very difficult to suggest legislation of any radical character that can supplant to advantage the natural law of supply and demand. For instance, the courts in Germany have sustained the agreements which we call restraint of trade agreements. The result of this has been that there have been fewer combinations in Germany. In this country laws have been passed against agreements between corporations for the purpose of regulating trade. Well, that very legislation has had a tendency to force organization of industrial combinations. The legislators who formulated the restraint of trade laws did not anticipate that those very laws would be one of the strongest reasons for bringing about the organization of industrial combinations. ${ }^{65}$

In summary, Flint saw the lack of appropriate incentives as a major cost of merger, he thought merger prevented price cutting during recessions but (reading between the lines) at a greater cost than price fixing, and he attributed a large fraction of the U.S. merger activity to the antitrust law.

\section{F. An Overview of Changing Industry Organization}

The costs associated with single-firm organization are also consistent with the determined search for some federative or decentralized industry

63 Charles R. Flint, The Gospel of Industrial Steadiness, in The Trust: Its Book 86 (1902).

64 Id. at 89.

${ }^{65}$ Id. at 225-26. 
organization, whether authentic trusts or other devices, such as pools, price-fixing agreements, holding companies, or "communities of interest," that were often called trusts. The specific circumstances of an industry dictated what was the best form of organization, subject to the constraints of the evolving antitrust law and of the formidable but limited creativity of corporation lawyers and company officials desirous of finding ways around the law. Broadly speaking, the legal attack on the trusts and cartels in the late 1880s led to the first round of mergers and, in one case, the first community of interest; the renewed attack on pools and price fixing led to merger through complete consolidation; and the holding company, whose potential was discovered in 1899 , became a popular merger device until it proved to be susceptible in 1904 to a rule of reason. Complete merger appears to have been a last resort in many cases. It is interesting that the most earnestly pursued monopoly, Standard Oil, was the first trust, the first community of interest, and the first of the new generation of holding companies in its various incarnations. ${ }^{66}$

One objection to the idea that mergers create diseconomies of management is that the firms in an industry can merge and achieve through internal decentralization the economies that come from independent responsibility and action. So, the argument goes, it cannot be true that the firms merged reluctantly and at the expense of a lower-cost form of organization. This observation has some drawbacks. First, it makes the question of industry organization open-ended, posing the same difficulty for the study of firm size as is usually implied by the assumption of constant returns to scale. If there were no costs to merger, why did firms not merge before 1898 ? Second, it breaks the connection between forms of business organization that are legal and any real or presumptive benefits. If there were no connection, then it would have been an easy matter to set up a sham corporation in the face of legal action against a cartel and continue as before. However, in practice, ownership rights of individual shareholders in a merged firm are general, and the concern of the shareholders will be to maximize the value of the entire enterprise. Consequently, this implies the necessity of imposing restrictions on managers who can no longer be allowed to maximize the value of individual plants because of the detrimental effect this would have on the firm as a whole. A sham merger, one in which the rights and obligations of shareholders were left unaffected, would very likely have come under attack

${ }^{66}$ This thumbnail sketch comes from Haney, supra note 32; and Chandler, The Visible Hand, supra note 48, chs. 9-11. Chandler in particular stresses the emergence of new administrative forms. This was an important long-term development that may have been accelerated or influenced by antitrust legislation, as Chandler suggests. Id. at 332-34. 
for abusing the corporate form, and the legal doctrines involved in "piercing the corporate veil" would have come into play. So, although merging firms can pick from a range of organizational forms, that range was probably not large enough to allow them to mimic exactly the incentives available under complete independence.

\section{Economists and the 1898-1902 Merger Wave}

The idea that antitrust policy played a significant role in the Great Merger Wave has received a cool welcome in modern studies of turn-ofthe-century antitrust policy and merger activity. It fared somewhat better in the first few decades after the mergers took place, although the topic never seemed worthy of extensive study. Lewis Haney, in an insightful analysis of the structure and function of various forms of business organization, mentioned the role of antitrust several times in passing. ${ }^{67}$ Eliot Jones devoted most of the chapter "The Modern Trust Movement" in his 1921 book The Trust Problem in the United States to a description of the various forms the trust could take, and he mentioned briefly that the antitrust laws had caused firms to adopt tight consolidations. ${ }^{68}$ He quoted the passage from United Shoe Machinery that suggests that antitrust policy may have caused merger in that case, but he did not comment on whether antitrust policy was a cause of the consolidation in the steel industry, focusing instead on "the desire to restrict or eliminate competition." ${ }^{69} \mathrm{~J}$. M. Clark speculated that the antitrust laws, among other factors, drove the cartels to merger, ${ }^{70}$ and a Brookings publication that appeared in 1939 emphasizes that Knight made merger legal, but attributes the mergers to the expansion of the late $1890 \mathrm{~s} .{ }^{71}$ Many of the classic works on the trust issue view the rise of the trust, broadly defined, as the main issue, and seem to regard the choice among trust forms as a relatively minor question. Consequently, they emphasize the nineteenth century's falling price level, the development of railroads, the rise of large scale production and similar long-term developments, but they do not mention antitrust. ${ }^{72}$

${ }^{67}$ Haney, supra note 32, at 205, 221, 242.

68 Jones, supra note 43 , at $390-91$.

69 Id. at 197, 199.

70 John Maurice Clark, Social Control of Business 381 (1939).

711 Leverett S. Lyon, Myron W. Watkins, \& Victor Abramson, Government and Economic Life 262-66 (1939).

72 See, for example, Charles S. Tippets \& Shaw Livermore, Business Organization and Public Control (1941). ch. 15; Henry R. Seager \& Charles A. Gullick, Trust and Corporation Problems (1929), ch. 5; and Jeremiah W. Jenks \& Walter E. Clark, The Trust Problem 
By the 1950s the notion was viewed with much skepticism. George Stigler gives primary consideration to changes in corporation law initiated by New Jersey in the late 1880s and to the growth of the New York Stock Exchange "into an effective market for industrial securities." growth of the exchange, Stigler argues, allowed promoters to capitalize monopoly gains. He plays down the role of antitrust. "The effectiveness of the Sherman Law in dealing with conspiracies was not clear until 1899, when the Addyston Pipe case was decided; and there was a contemporaneous wave of amalgamations in England, where conspiracies were unenforceable but not actionable." 74

I have tried to show that the decisions before 1899 should not be discounted and that the British mergers did not necessarily result from the same influences. Looking at corporation law and securities markets as "causes" also raises questions. U.S. railroad securities were traded for many decades before 1900 in both the United States and the United Kingdom. ${ }^{75}$ It is difficult to imagine that the liquidity of securities markets increased so rapidly because of innovations in communication, say, that one industry after another became consolidated in a five-year period. It seems just as sensible to say that the formation of large firms increased the demand for liquid securities markets.

The role of the new corporation laws is also less than clear. New Jersey allowed holding companies and permitted corporations to exchange stock for property in 1889 , nine years before the merger wave began. Other states soon passed similar legislation. ${ }^{76}$ It is possible that states competed for corporations following the actions taken against trusts in the late 1890 s. Another fact that has to be faced is that a number of industrial and railroad mergers took place between 1888 and 1893, proving that it could be done. Why did most firms wait until after 1897? In addition, corporations could consolidate before 1889 with special permission of state legis-

(1917), ch. 3. Nelson, supra note 40, ch. 4, examines four explanations: "retardation of industrial growth; the immediately preceding expansion of the national railroad system; the growth of a highly organized capital market; the increase of motivation toward market control." Id. at 71. Eichner, supra note 16, at 93-119, also surveys these and related hypotheses.

${ }^{73}$ Stigler, supra note 5, at 101.

${ }^{74} \mathrm{Id}$. at 102 (footnote omitted).

75 Nelson, supra note 40 , at 89 , notes that causation could run from mergers to the stock market as well as in the opposite direction. His data show no marked increase in the number of listed issues in the 1890s, although the number of shares traded does increase about threefold from 1896 to 1899 . Id. at 90 , chart 4 . Nelson also notes the earlier development of the British capital market. Id. at 133.

${ }^{76}$ Haney, supra note 32 , at 220-21. Eichner, supra note 16 , at 150 , concludes that the New Jersey laws were not necessary, but merely convenient. 
latures; they could purchase property; and some conducted sub rosa holding company relations. ${ }^{77}$ The community of interest, used by Standard Oil in the 1890 s and after its dissolution in 1911 was also an alternative. ${ }^{78}$

Jesse Markham is also inclined to give a minor role to antitrust policy in a 1955 survey of merger movements. ${ }^{79}$ His study reviews evidence linking business activity and merger, and he evaluates various explanations for the merger movements at the turn of the century, the 1920s, and the 1940s. He concludes that the timing and scope of the first wave "defies precise analysis" and mentions the Sherman Act only briefly. ${ }^{80}$ Markham is taken to task for this by Walter Adams, who emphasizes "the crucial E. C. Knight decision." ${ }^{81}$ In a more recent study of the Sugar Trust, Alfred Eichner also stresses the influence of this case. ${ }^{82}$

Hans Thorelli, in a book-length study of turn-of-the-century antitrust policy also published in 1955 rejects the view that antitrust may have done more than stimulate a few mergers, claiming that the probability of prosecution was too low. "It would be a vast exaggeration to say that the two railroad cases were a decisive factor in inducing restriction-minded businessmen to choose tight rather than loose combinations," he concludes. ${ }^{83}$

Ralph Nelson, author of an NBER study that provides an authoritative compilation and analysis of U.S. merger statistics, also looks at antitrust

77 Jones, supra note 43, at 29-38; and Thorelli, supra note 14, at 83. 2 Victor S. Clark, History of Manufactures in the United States, 1860-1914 (1928), at 284, mentions several mergers in the 1880s in iron and steel. In addition, the holding company played a role only after the merger wave got underway. Haney, supra note 32, at 238, says that "just prior to the great holding company epoch which began in 1899 and reached its climax between that date and 1904, a number of consolidations of a different type arose-complete consolidations." Jones, supra note 43, at 31, makes a similar claim. See also Thorelli, supra note 14, at 258 .

${ }^{78}$ Haney, supra note at 32, at 205. Posner \& Easterbrook, supra note 3, at 411 , mention that Standard Oil assumed the form of a community of interest following its dissolution in 1911.

${ }^{79}$ Markham, supra note 39.

80 Id. at 166.

81 Walter Adams, Comment, in Business Concentration and Price Policy: A Report of the National Bureau of Economic Research 182, 189-90 (1955).

${ }^{82}$ Eichner, supra note 16, at 186-87.

83 Thorelli, supra note 14 , at 258-59. Thorelli makes his view unmistakable in a footnote where he mentions Charles Washburn's claim that "the anti-trust legislation made the trusts." Thorelli responds that "this is not a paradox but an absurdity." Id. at 259, n.77. The most remarkable part of Washburn's article is part of an opinion given by Senator George F. Hoar, a coauthor of the Sherman Act, concerning a proposed pooling arrangement. This opinion was solicited in 1891 by the members of a pool to determine whether it would be in violation of the new antitrust law. It may be surprising to the modern reader to discover that the senator thought that a pool established as a defense against "destructive competition" would not be illegal. See Charles G. Washburn, The History of a Statute, 8 B. U. L. Rev. 95 , 101 (1928). 
policy but finds the timing of the late 1890 s mergers to be ambiguous. ${ }^{84}$ In addition, Nelson contends that the 1888-92 mergers could not be explained by the later cases. As I have tried to show, the timing of the mergers is actually fairly consistent, and the earlier mergers occurred when the trusts first felt an ill wind.

\section{An Econometric Study of Antitrust Policy and Mergers}

There were several swings in merger and cartel policy following the 1904 Northern Securities decision. Standard Oil and American Tobacco were broken up, and tougher antitrust standards were written into the Clayton and Federal Trade Commission Acts. The Taft and Wilson administrations, during which these two pieces of legislation were considered and passed, had a particularly strong antimerger policy. This is reflected in the large number of "monopolization" cases filed in the years $1910-14 .^{85}$

At other times antitrust was more of a paper tiger. The government tried but failed to break up U.S. Steel, and merger policy was very lax in the 1920s. The per se rule against price fixing was scuttled in 1911 in Standard Oil and not firmly reestablished until 1927 in Trenton Potteries. ${ }^{86}$ Throughout the intervening years, cases involving trade associations added to the uncertainty about what the Sherman Act did and did not prohibit. ${ }^{87}$ Strenuous efforts were made during Theodore Roosevelt's second term, in the years before the Clayton Act was passed, and in the late 1920s and early 1930s to rewrite the antitrust laws to allow at least regulated price fixing. ${ }^{88}$ This end was briefly achieved with the National Recovery Act cartelizations. Even the Supreme Court's resolve sagged in Appalachian Coals. ${ }^{89}$ Finally, the Roosevelt administration reversed its course and adopted a stringent antitrust policy in the late 1930s and early 1940s. ${ }^{90}$

\footnotetext{
${ }^{84}$ Nelson, supra note 40 , at 135 . Nelson is also inclined to interpret the British merger wave as evidence that U.S. antitrust policy did not cause the U.S. mergers.

${ }^{85}$ Posner, supra note 36, at 398.

86 Standard Oil v. United States, 221 U.S. 1 (1911); and United States v. Trenton Potteries, 273 U.S. 392 (1927). See the commentary in Posner \& Easterbrook, supra note 3, at 114.

87 Tippets \& Livermore, supra note 72, at 297-310, review this development. They credit Arthur J. Eddy, The New Competition (1911), with stimulating the formation of these associations, which were known until the 1920 s as open price associations. Posner, supra note 36 , at 398, reports a sharp increase in the number of trade association and information exchange cases for the years 1920-24.

${ }^{88}$ See J. D. Clark, The Federal Antitrust Policy (1931), chs. 6-11; and Robert F. Himmelberg, The Origins of the National Recovery Administration (1976).

${ }^{89}$ Appalachian Coals v. United States, 288 U.S. 344 (1933).

90 Ellis W. Hawley, The New Deal and the Problem of Monopoly (1966).
} 


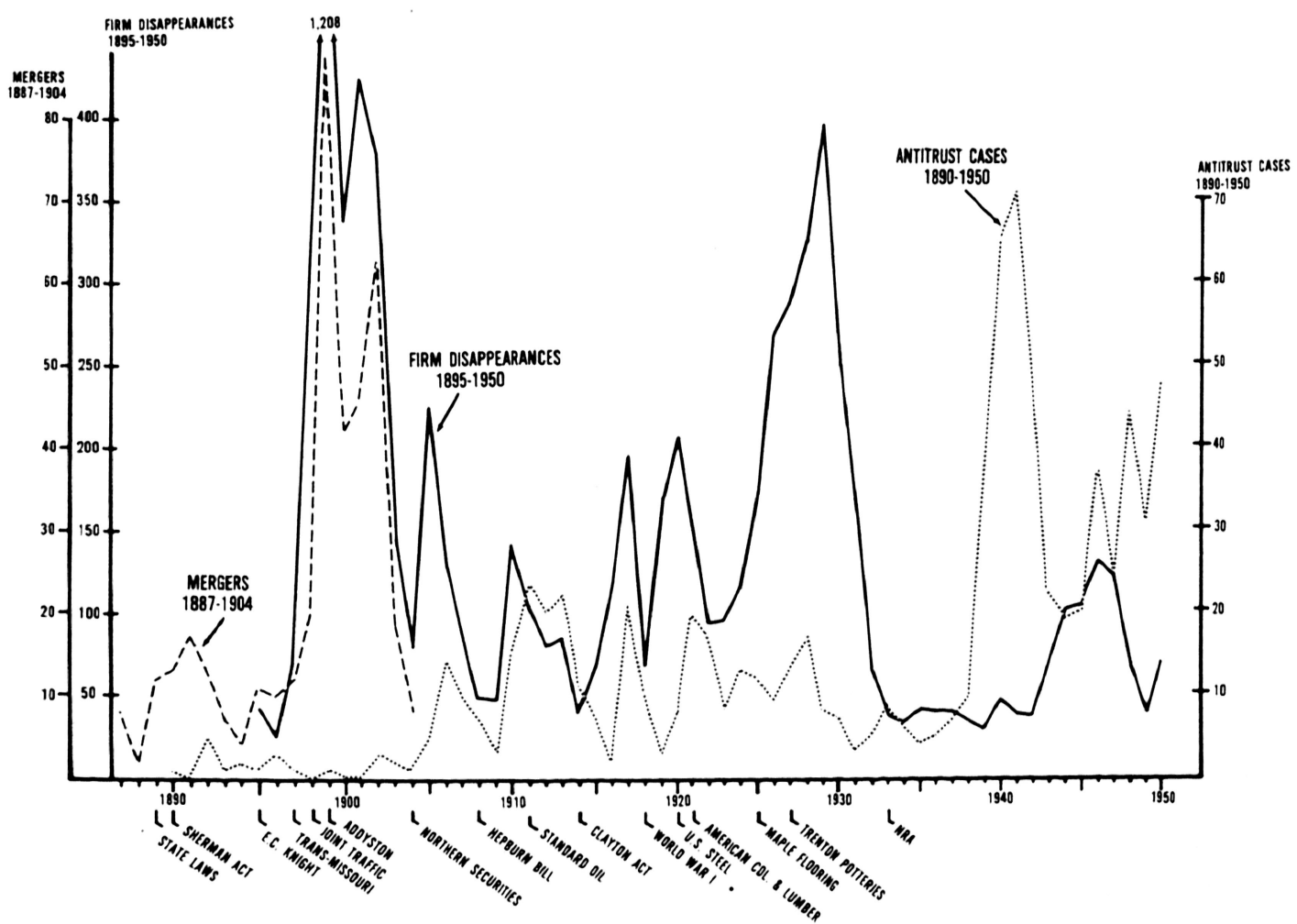

FIGURE 1.-Antitrust cases instituted by the Justice Department and merger activity, 18871950. (Antitrust cases instituted by the Department of Justice are from Richard A. Posner, A Statistical Study of Antitrust Enforcement, 13 J. Law \& Econ. 365, 366 (1970). Mergers, 1887-1904, come from Jesse W. Markham, Survey of the Evidence and Findings on Mergers, in Business Concentration and Price Policy 141, 149 (1955). Firm disappearances, 18951970 and 1919-1950, are from Ralph L. Nelson, Merger Movements in American Industry, 1895-1956 (1959), Table C-7 at 164-169.)

Figure 1 shows the number of antitrust cases instituted by the Department of Justice for the years 1890-1950. It also shows several merger series that jointly cover the same period. The number of cases is a poor measure of antitrust policy, in part because this aggregate lumps together price fixing and other types of cases. But we have to make do. Important developments for antitrust, which should also have an effect on merger, are marked below the graph.

Beginning in 1904 and up to the late 1940s, there seems to have been a connection between the two series. This covers the period between Northern Securities and the Cellar-Kefauver Amendment. Between 1904 and the early 1920s there are four cycles of antitrust enforcement matched by four cycles of merger activity. The first ended in 1908, when the Hepburn Bill-a legislative proposal that would have allowed price fixing - was being considered. That effort failed, and mergers increased sharply and then decreased during the years that reform of the antitrust 
laws was being considered again, hitting their lowest point for the years 1900-1920 in 1914, when the legislative labor gave birth to the FTC and Clayton Acts. The third and fourth cycles are really one, interrupted by the First World War, when industry was cartelized by government.

One feature of this data, confirmed below in econometric results, is the tendency for changes in merger activity to lead changes in case filings. This can mean either that merger caused more cases to be filed or that case filings represented earlier changes in policy. Although yearly data on the number of merger and price-fixing cases are not available, five-year averages of charges filed from 1904 through 1925 indicate that only 18 percent of all cases involved monopolization charges, while 71 percent involved horizontal agreements. ${ }^{91}$ Note also that the number of cases filed underwent fairly dramatic swings, making it unlikely that budget cutbacks due to business cycles or other extraneous factors caused the periodic declines in case filings if the Department of Justice operated under roughly constant returns to scale.

The 1920s merger wave is usually considered to be the second important one after the 1898-1902 movement. The actual "wave" can probably be dated at 1925-29. Carl Eis emphasizes the lax merger policies in his study of these mergers. ${ }^{92}$ This is consistent with the evidence from the earlier merger wave, but the two periods may have had an increasingly stringent cartel policy in common as well. Not only did the Supreme Court reestablish the per se rule in 1927 in Trenton Potteries, but the number of horizontal conspiracy cases filed in 1920-24 (fifty cases) and 1925-29 (thirty-six cases) was greater than in all preceding five-year periods except 1910-14. It was also greater than in the next two five-year periods. ${ }^{93}$ A renewed effort to change the antitrust laws followed the 1927 case, and case filings also decreased. The number of mergers decreased at the same time, remaining low through the first two terms of the Roosevelt administration. However, case filings increased substantially in the late 1930s and early 1940s, and the number of mergers increased directly after this 180 degree change in policy. This sort of graph reading certainly does not prove a connection, but it does provide the outlines of one explanation for large swings in merger activity before passage of the CellarKefauver Amendment and before price fixing had become illegal permanently and beyond all doubt.

${ }^{91}$ Posner, supra note 36, at 398.

92 Carl Eis, The 1919-1930 Merger Movement in American Industry, 12 J. Law \& Econ. 267, 284-92 (1969).

${ }^{93}$ Posner, supra note 36 , at 398 . Himmelberg, supra note 88 , at 54-57, argues that Republican policy in the mid-1920s, although lenient toward trade association activities, was severe with regard to out-and-out price fixing. 
Some statistical results support the likelihood of a link between mergers and case filings. In the results that follow yearly merger activity for the years 1895-1920 is regressed on case filings, stock price changes, and dummy variables covering periods where antitrust policy underwent changes. Stock price changes are included because the weak statistical association between stock prices and merger is one explanationalthough an explanation without a theory-that has often been proposed as a cause of cycles in merger activity. The dummy variables are a necessary evil because they are the only way of taking into account the key policy changes. The problem with using dummies, of course, is that the data are made up, so to speak, and given enough dummies, it would be possible to explain just about any time series. I will define three: one for 1898-1902 (the period between Trans-Missouri and the initiation of Northern Securities); 1899 (the year following Joint Traffic and the Addyston Court of Appeals decision); and 1896 and 1908-16 (the period covering the Hepburn Bill, the "monopolization" prosecutions of the Taft administration, the FTC and Clayton Acts, and the creation of exempt industries, as well as the 1896 political uncertainty).

The most striking feature of Table 6 is that the dummy variables for 1898 and 1898-1902 provide strong and consistent support for the view that those years were special, even taking into account the influence of stock prices. The dummy for policy uncertainty $(1896,1908-16)$, on the other hand, shows a strong negative effect. Also of interest, the number of antitrust cases has as much explanatory power as stock returns. Current stock returns are more strongly related than either lagged or leading stock returns. In contrast, antitrust cases from past years are negatively related and from future years positively related to merger. Since case filings represent policy initiatives that had their origins before a given case was filed, the negative association of earlier case filings with current mergers suggests at first glance the perverse inference that mergers in the current period are stimulated by a lax price-fixing policy initiated more than a year ago. This is probably a statistical fluke that comes from the see-saw nature of antitrust enforcement. The positive association of next year's case filings with current merger activity comes closer to capturing an intelligible relationship since it takes time to prepare cases and since an administration will usually reveal before case filings are made what its stance on antitrust issues will be. ${ }^{94}$

${ }^{94}$ My results contrast with those of Michael S. Lewis-Beck, Maintaining Economic Competition: The Causes and Consequences of Antitrust, 41 J. Pol. 169 (1979), who finds no relation between antitrust enforcement and mergers. He uses Department of Justice case filings as the dependent variable and mergers as the independent variable to assess whether "less competition" (more mergers) causes a change in antitrust enforcement for the years 


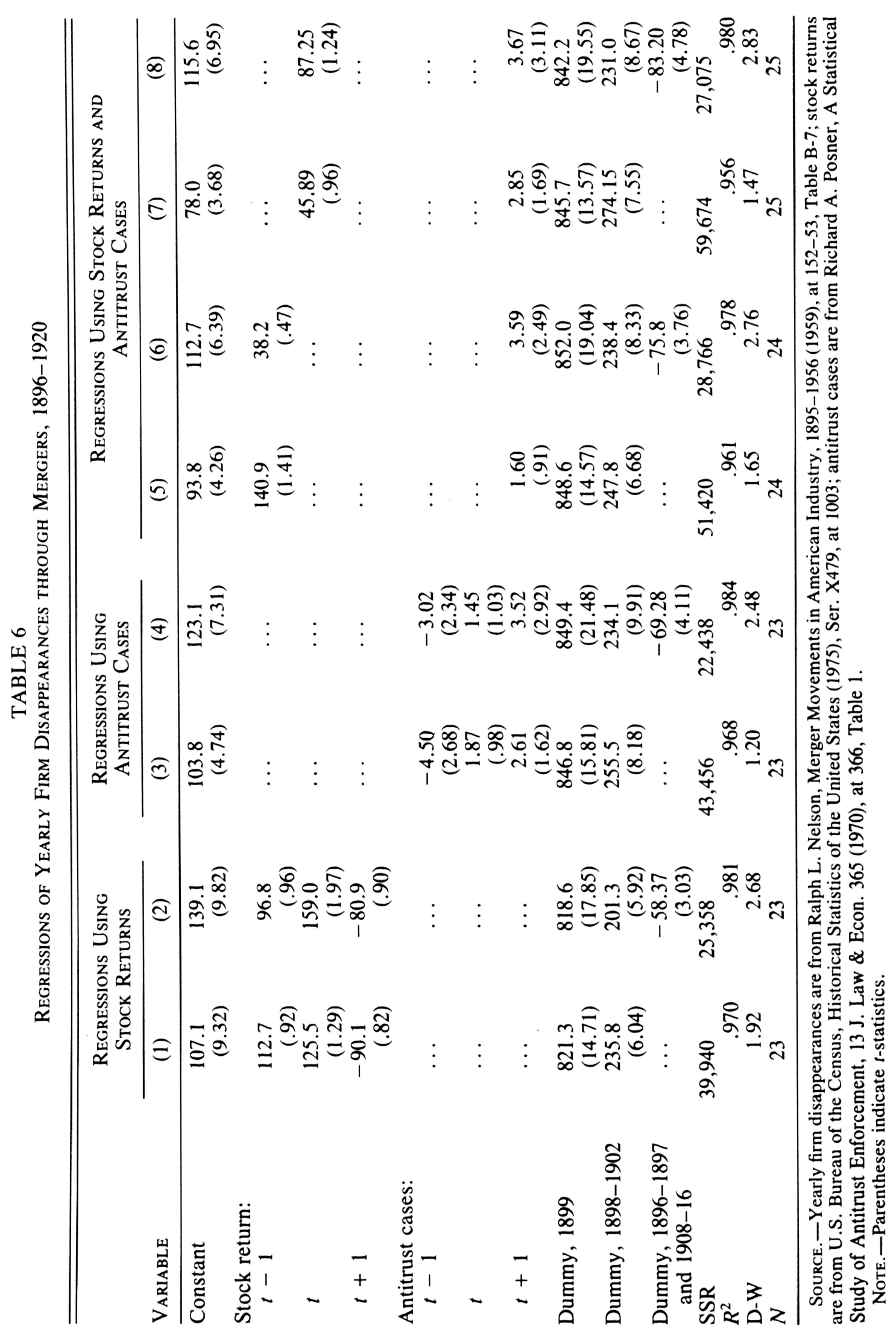


The last two columns of Table 6 show that when filings are used as explanatory variables the effect that can be credited to stock returns falls off. My guess about this is that stock prices partly changed in response to developments in antitrust. The Dow-Jones average used in these regressions was composed chiefly of railroad stocks and stocks of corporations that had been formed in the 1898-1902 merger wave, and these are precisely the firms that had an interest in the interpretation and enforcement of the Sherman Act. As each of several crises in antitrust policy came and went (the years 1904, 1908, and 1914 provide examples), stock prices may have dropped and then risen as it became clear that more radical solutions to the trust problem - such as dissolution of firms that happened also to be in the Dow-Jones index-were being passed up in favor of renewed dedication to catching price fixers. ${ }^{95}$ Similar arguments would hold for more broadly defined indexes, since a large fraction of industrial stocks were issued by firms formed in the Great Merger Wave.

The results so far have used firm disappearances through merger in mining and manufacturing as the dependent variable. Examination of the data revealed that mining disappearances, chiefly in coal mining, accounted for a large fraction of disappearances (17 percent for the years 1895-1920) and were very variable. For example, they accounted for 43 percent of the total in 1905. In addition, it seemed desirable to break down the regressions by the two types of merger, consolidation and acquisition. The regression results in Table 7 show an even weaker effect of stock returns on manufacturing disappearances than on manufacturing and mining disappearances. They also show a much stronger relation between antitrust case filings and acquisition than between antitrust case filings and consolidation. On the other hand, consolidation seems largely to have been a response to events in 1898-1902 and does not appear to have been affected at all by the periods of "policy uncertainty" $(1896,1908-16)$ or by case filings. One possibility is that acquisition was more sensitive to the antitrust climate, but it seems more likely that the large number of consolidations in the years 1898-1902 imparted so much variability to the data over those years that the more subtle effects of case filings and the periods of policy uncertainty are lost.

1895-1973. This raises the question why increased merger activity should cause more pricefixing cases to be filed if mergers and price fixing are substitutes. In addition, Lewis-Beck uses one regression equation for the entire period, uses no trend or trendlike variable, and makes no attempt to incorporate the possible effects of court cases.

95 From the Wall Street Journal, January 6, 1909, at 8, it can be established that six of the twelve industrials in the Dow Jones index are in a list of consolidations in Thorelli, supra note 14, at 294-303. A study based on stock market data by Malcom R. Burns, The Competitive Effects of Trust-Busting: A Portfolio Analysis, 85 J. Pol. Econ. 717 (1977), finds that the dissolution ordered for Standard Oil was not as severe as expected. 
TABLE 7

Regressions of Manufacturing Firms Disappearances Broken Down by Consolidations AND ACQuisition, 1896-1920

\begin{tabular}{lccc}
\hline \hline & \multicolumn{3}{c}{ Dependent Variable: Manufacturing DisapPearances BY: } \\
\cline { 2 - 4 } & $\begin{array}{c}\text { Consolidation } \\
\text { and Acquisition }\end{array}$ & Consolidation Only & Acquisition Only \\
\hline VARIABLE & 86.5 & 37.47 & 49.08 \\
Constant & $(6.88)$ & $(3.95$ & $(5.14)$ \\
& -8.78 & 8.09 & -16.87 \\
Stock return $t$ & $(.17)$ & $(.20)$ & $(.42)$ \\
& 2.49 & .23 & 2.26 \\
Antitrust cases $t+1$ & $(2.78)$ & $(.33)$ & $(3.33)$ \\
& 696.0 & 646.7 & 49.33 \\
Dummy, 1899 & $(21.33)$ & $(26.31)$ & $(1.99)$ \\
& 198.4 & 198.1 & .29 \\
Dummy, 1898-1902 & $(9.82)$ & $(13.03)$ & $(.19)$ \\
& -52.71 & -9.20 & -43.51 \\
Dummy, 1896-97 & $(4.00)$ & $(.93)$ & $(4.35)$ \\
and 1908-16 & .982 & .989 & .619 \\
$R^{2}$ & 1.98 & 2.43 & 1.36 \\
D-W & 25 & 25 & 25 \\
$N$ & & & \\
\hline
\end{tabular}

Source.-Same as Table 6.

\section{CONCLUSION}

Did antitrust policy cause the merger wave that began in the late 1890 s? An assessment of what the key court decisions said and how they were interpreted makes it reasonable to suppose that merger was legal while cartels were not. This was at least a widespread view, and these decisions (Knight, Trans-Missouri, Joint Traffic, and Taft's Addyston opinion) enjoyed prominent play in newspapers and legal publications.

The timing of the mergers is consistent with this story. There was a brief flurry of mergers in the late 1880s-around the time the first antitrust laws were passed and the trusts were first brought into the courts. There was another increase after E. C. Knight, and finally an unprecedented number of mergers in 1898 following a new outcry against the trusts and a series of court cases that held price fixing to be illegal. Merger activity decreased substantially while Northern Securities was litigated.

Other evidence comes from particular industries. The mergers in several industries-cotton oil, sugar, cast iron pipe, oil, and meat packingappear to have been the result of antitrust action taken against cartels in those industries. In other cases-shoe machinery and explosives- 
merger was apparently undertaken on the advice of attorneys worried about the antitrust laws. Steel and railroading, two heavily cartelized industries, resorted to merger at a substantially greater pace beginning in 1898 , and a major promoter of consolidations claimed that the antitrust laws increased the number of U.S. mergers. In addition to merger, another device, the community of interest, seems also to have sprung up in the late 1890s in railroading as a substitute for cartel agreements.

Data from later years suggest that antitrust policy continued to influence the number of mergers. Northern Securities resulted in fewer consolidations and more acquisitions. There is a strong, positive statistical relationship between merger and the number of antitrust case filings during the years 1904 to 1920, and a more casual investigation suggests that the merger wave of the late 1920s may have been related to increased case filings and the reestablishment of the per se rule, and that the merger wave of the 1940s may have been a response to the antimonopoly campaign of 1939-42.

Any explanation has to be evaluated against the alternatives. The mergers grew so rapidly and encompassed so many different industries that it seems reasonable to look first at policy intervention-a change in corporation laws or a change in cartel policy, for example. The obvious difficulty with the corporation law argument is that the laws were changed a decade before the mergers took place. It also begs the question, Why was the law changed? It seems more reasonable, I think, that mergers in 1898 and 1899 were caused by court cases decided in 1897 and 1898 . While the British mergers of the 1880s and 1890s represent a challenge to this seemingly straightforward interpretation of the evidence, it seems defensible at the very least to say that the U.S. merger movement was larger and more pronounced by a great enough margin to merit special attention.

I have also tried to revive an old controversy that the evidence seems to invite. Were the cartels and mergers caused by the desire for monopoly or by the desire to prevent ruinous competition? Both explanations are consistent with the notion that the 1898-1902 mergers were caused by the court cases of 1897 and 1898 . However, many firms apparently preferred the less secure collusion of a cartel until the late 1890s, suggesting that the monopoly gains from merger may not have been very great. So it certainly seems worthwhile to consider explanations that do not posit monopoly gain as the reason for collusion and for merger induced by a law against price fixing.

The view that collusion and merger were both responses to unavoidable market imperfections stemming from fixed costs has some advantages considered purely as theory, and it also receives some support from the 
disproportionate representation of the iron and steel industry in the peak years of 1898-1902, as well as from the prominent cartelization, merger, and development of communities of interest in railroading. The implication, only thinly sketched here, that there can be too much competition is also in harmony with the view of turn-of-the-century businessmen and economists, which seems to me to be a happy result if it can be achieved on an economically defensible basis. But, while I hope to have aided in the rehabilitation of a way of looking at competition and monopoly, much remains to be done. 